NATIONAL LABORATORY MANAGED BY UT-BATTELLE FOR THE DEPARTMENT OF ENERGY

\section{OVERVIEW OF THE SAFETY ISSUES ASSOCIATED WITH THE COMPRESSED NATURAL GAS FUEL SYSTEM AND ELECTRIC DRIVE SYSTEM IN A HEAVY HYBRID ELECTRIC VEHICLE}

Samuel C. Nelson

Oak Ridge National Laboratory 


\section{DOCUMENT AVAILABILITY}

Reports produced after January 1, 1996, are generally available free via the U.S. Department of Energy (DOE) Information Bridge.

Web site http://www.osti.gov/bridge

Reports produced before January 1, 1996, may be purchased by members of the public from the following source.

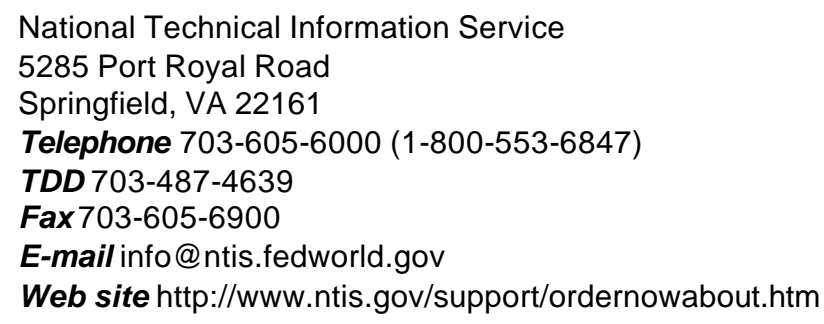

Reports are available to DOE employees, DOE contractors, Energy Technology Data Exchange (ETDE) representatives, and International Nuclear Information System (INIS) representatives from the following source.

Office of Scientific and Technical Information

P.O. Box 62

Oak Ridge, TN 37831

Telephone 865-576-8401

Fax 865-576-5728

E-mail reports@adonis.osti.gov

Web site http://www.osti.gov/contact.html

This report was prepared as an account of work sponsored by an agency of the United States Government. Neither the United States Government nor any agency thereof, nor any of their employees, makes any warranty, express or implied, or assumes any legal liability or responsibility for the accuracy, completeness, or usefulness of any information, apparatus, product, or process disclosed, or represents that its use would not infringe privately owned rights. Reference herein to any specific commercial product, process, or service by trade name, trademark, manufacturer, or otherwise, does not necessarily constitute or imply its endorsement, recommendation, or favoring by the United States Government or any agency thereof. The views and opinions of authors expressed herein do not necessarily state or reflect those of the United States Government or any agency thereof. 
ORNL/TM-2002/238

\section{Engineering Science \& Technology Division}

\section{Overview of the Safety Issues associated with the Compressed Natural Gas Fuel System and Electric Drive System in A Heavy Hybrid Electric Vehicle}

Samuel C. Nelson

September 2002

Prepared by the

OAK RIDGE NATIONAL LABORATORY

Oak Ridge, Tennessee 37831

managed by

UT-BATTELLE, LLC

for the

U.S. DEPARTMENT OF ENERGY

Under contract DE-AC05-00OR22725 


\section{Table of Contents}

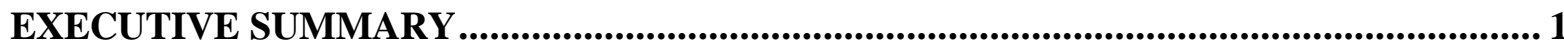

1. INTRODUCTION AND SUMMARY OF FINDINGS ............................................ 2

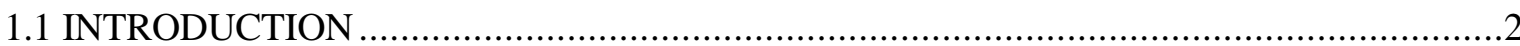

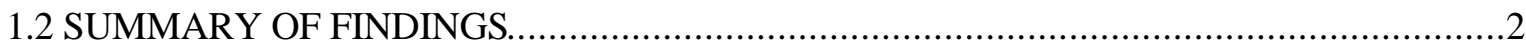

2. DISCUSSION OF UNIQUE VEHICLE DESIGN FEATURES....................................... 4

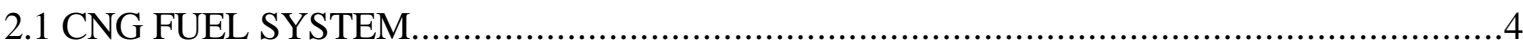

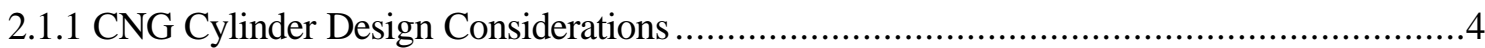

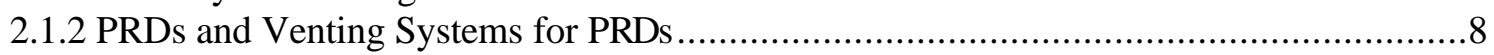

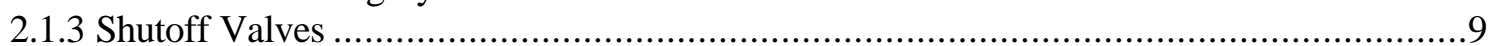

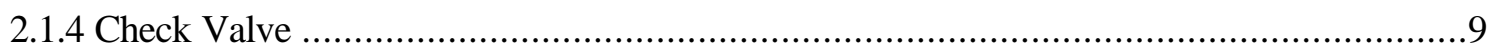

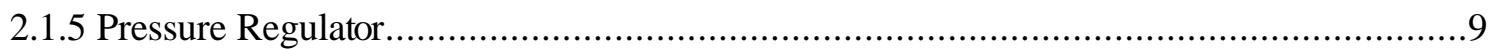

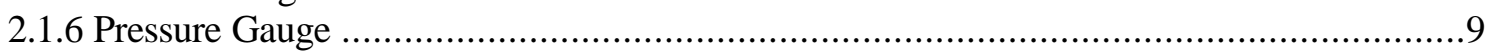

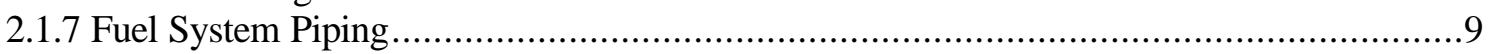

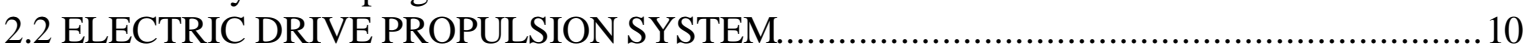

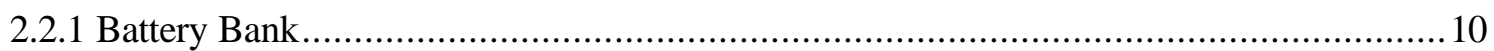

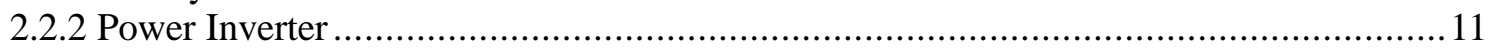

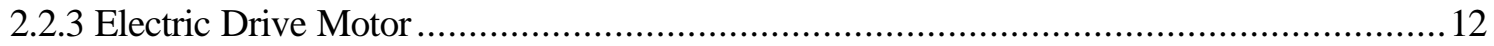

2.2.4 Automatic and Manual Disconnect.............................................................. 12

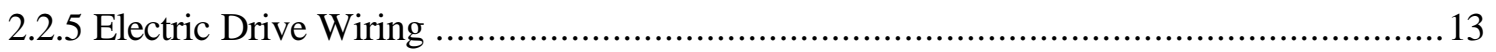

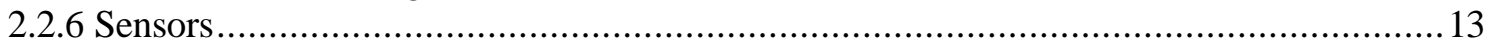

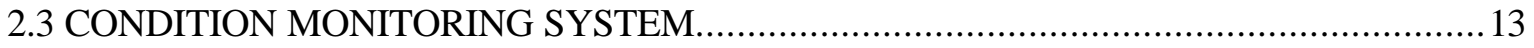

3. PROPERTIES OF GASES AND MATERIALS.............................................................. 16

3.1 NATURAL GAS AND COMPRESSED NATURAL GAS.......................................... 16

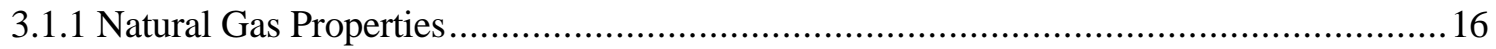

3.1.2 Compressed Natural Gas Properties ................................................................ 17

3.1.3 Comparison of CNG with Gasoline and Diesel Fuel.......................................... 18

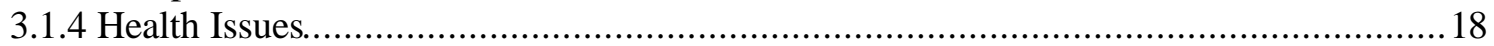

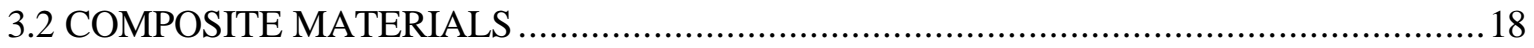

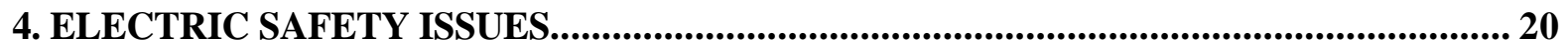

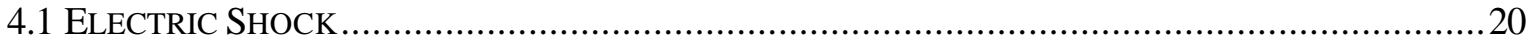

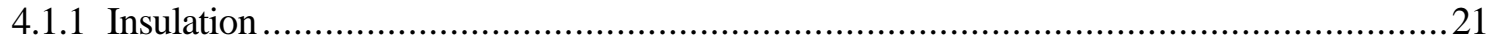

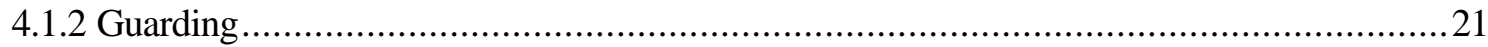

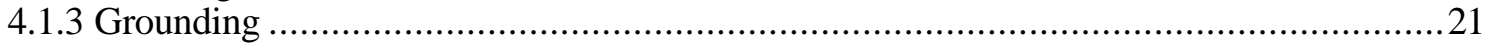

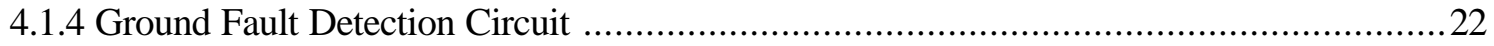

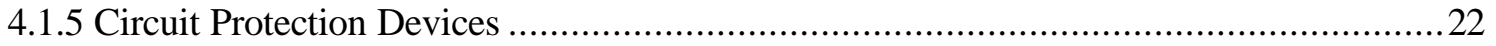

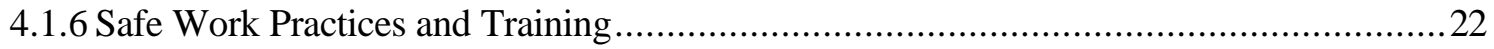

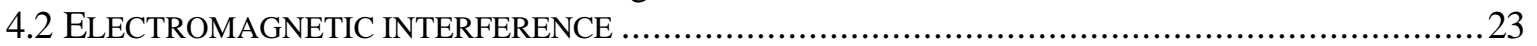

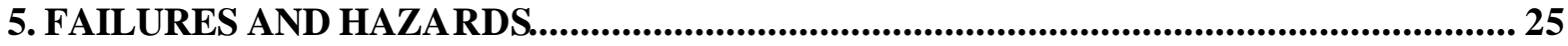

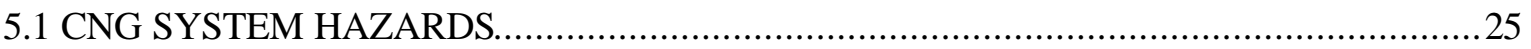

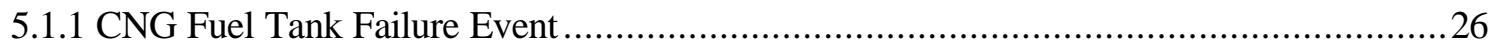




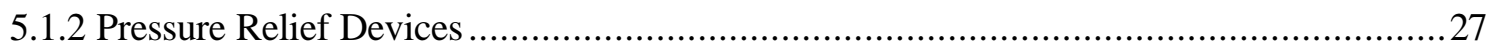

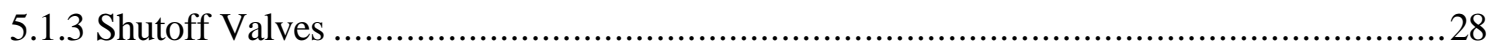

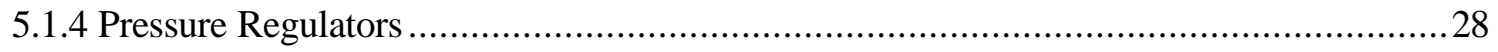

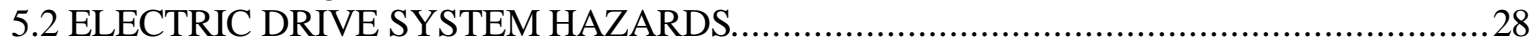

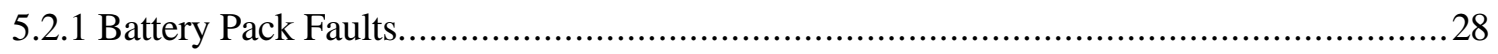

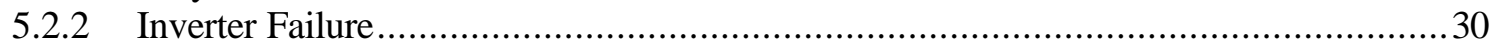

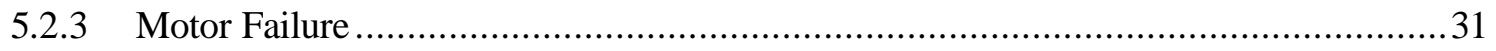

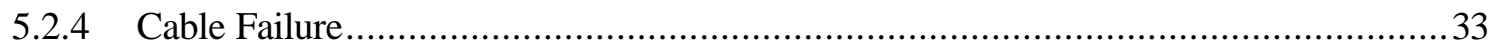

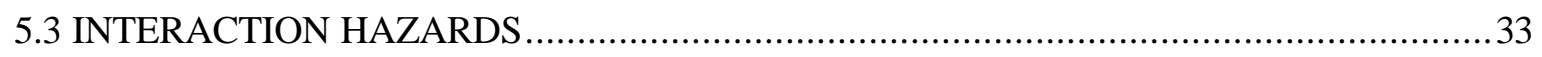

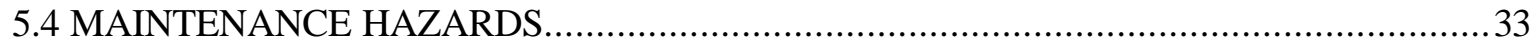

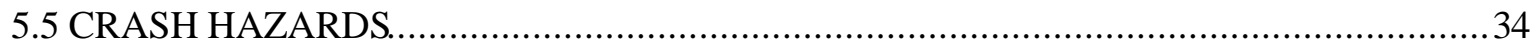

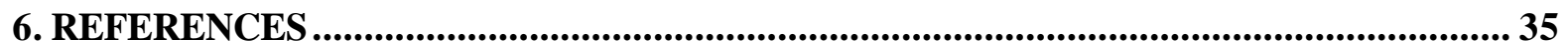

7. TABLE 1. DESIGN CHARACTERISTIC MATRIX............................................. 37

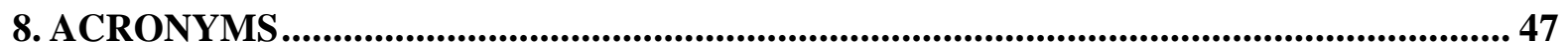




\section{EXECUTIVE SUMMARY}

This report evaluates the hazards that are unique to a compressed-natural-gas (CNG)-fueled heavy hybrid electric vehicle (HEV) design compared with a conventional heavy vehicle. The unique design features of the heavy HEV are the CNG fuel system for the internalcombustion engine (ICE) and the electric drive system. This report addresses safety issues with the CNG fuel system and the electric drive system.

Vehicles on U. S. highways have been propelled by ICEs for several decades. Heavy-duty vehicles have typically been fueled by diesel fuel, and light-duty vehicles have been fueled by gasoline. The hazards and risks posed by ICE vehicles are well understood and have been generally accepted by the public. The economy, durability, and safety of ICE vehicles have established a standard for other types of vehicles. Heavy-duty (i.e., heavy) HEVs have recently been introduced to U. S. roadways, and the hazards posed by these heavy HEVs can be compared with the hazards posed by ICE vehicles.

The benefits of heavy HEV technology are based on their potential for reduced fuel consumption and lower exhaust emissions, while the disadvantages are the higher acquisition cost and the expected higher maintenance costs (i.e., battery packs). The heavy HEV is more suited for an urban drive cycle with stop-and-go driving conditions than for steady expressway speeds. With increasing highway congestion and the resulting increased idle time, the fuel consumption advantage for heavy HEVs (compared with conventional heavy vehicles) is enhanced by the HEVs' ability to shut down. Any increase in fuel cost obviously improves the economics of a heavy HEV.

The propulsion system for a heavy HEV is more complex than the propulsion system for a conventional heavy vehicle. The heavy HEV evaluated in this study has in effect two propulsion systems: an ICE fueled by CNG and an electric drive system with additional complexity and failure modes. This additional equipment will result in a less reliable vehicle with a lower availability than a conventional heavy vehicle. Experience with heavy HEVs to date supports this observation.

The key safety concern for the electric drive system is the higher voltages and currents that are required in the electric drive system. Faults that could expose personnel to these electric hazards must be considered, addressed, and minimized. The key issue for the CNG-fueled ICE is containment of the high-pressure natural gas. Events that can result in a release of natural gas with the possibility of subsequent ignition are of concern. These safety issues are discussed. The heavy HEV has the potential to have a safety record that is comparable to that of the conventional vehicle, but adequate attention to detail will be required. 


\section{INTRODUCTION AND SUMMARY OF FINDINGS}

\subsection{INTRODUCTION}

This task was funded by the U. S. Department of Energy (DOE) Heavy Hybrid Program with the objective of assessing the unique safety issues that are presented by a heavy hybrid electric vehicle (HEV) compared with a conventional heavy vehicle. The propulsion system for a heavy HEV will include a smaller internal combustion engine (ICE) and an electric drive system powered by battery packs. When the study was initiated, the specified fuel for the ICE was compressed natural gas (CNG). The CNG fuel system and the electric drive system are analyzed in this report.

Hybrid technology has the potential to reduce the pollution produced per vehicle mile and to increase the fuel economy, especially in an urban driving scenario. This vehicle is most appropriately designed to operate in an urban environment where the electric drive system can be utilized more effectively in a stop-and-go-type drive cycle. The incorporation of hybrid technology into large vehicles must not reduce the inherent safety of these vehicles. The scope of this evaluation is limited to the identification and discussion of the key safety issues of the CNG fuel system and the electric drive system in a heavy HEV.

\subsection{SUMMARY OF FINDINGS}

The propulsion system for a heavy HEV is more complex than the propulsion system for a conventional heavy vehicle since a heavy HEV has in effect two propulsion systems. This additional complexity and equipment will result in a less reliable (durable) vehicle with a lower availability than that of a conventional heavy vehicle. Experience with heavy HEVs to date supports this observation.

The key safety issue for the CNG fuel system is the containment of the high-pressure natural gas. Events that can result in a release and subsequent ignition of large quantities of a flammable fuel/air mixture are the event of concern for the CNG fuel system. Large fuel leaks can produce a large cloud of a flammable mixture that is equal to several gallons of fully vaporized gasoline. There is a reduced danger if the ignition occurs shortly after the initiation of the leak because only a small volume of gas would accumulate, therefore avoiding a powerful explosion. Once there is ignition of natural gas, the primary subsequent danger is overheating of CNG containers. CNG fuel system standards place requirements on key system components (e.g., design, material of construction, maintenance, location), and adhering to these standards should limit the frequency of CNG leaks or loss of ability to depressurize a container (e.g., during a fire).

Standards for $\mathrm{CNG}$ vehicle maintenance facilities should be followed (e.g., ventilation system, electrical system, and heaters) to prevent the accumulation of a flammable mixture near the ceiling and the subsequent ignition. Inadvertent opening of valves or loosening of fittings containing high-pressure natural gas can result not only in the creation of a fire hazard, but also in the high-velocity ejection of metal parts or fragments that can be lethal to 
nearby personnel. Training will be essential to address the hazard of a high-pressure gas since a large percentage of vehicle operations and maintenance personnel will have no experience with CNG fuel systems. Section 5.1 contains additional detail about CNG fuel system faults.

The key safety concern for the electric drive system is electric shock due to the voltage and current levels associated with that system. The chassis of the heavy HEV will be used as a floating reference plane for the electric drive system components. More than one fault condition must occur for an occupant of a heavy HEV to receive a serious electric shock. For example, a person could access the positive $(+)$ direct current $(\mathrm{dc})$ bus (i.e., link) voltage and not receive an electric shock because the vehicle frame is floating (i.e., not grounded). Two events are required to receive a shock: the person must access the $+\mathrm{dc}$ bus and the negative $(-)$ dc bus. Battery fire events are also a concern because of the potential for dissipation of electrochemical energy internally in a faulty battery pack. Short-circuit events are a concern associated with the inverter because they can cause extremely high currents and resulting equipment damage. The electric drive system should be monitored for out-of-limit conditions (high or low battery voltage, high current, and imbalance in the currents) or for indications of a ground fault. The sum of currents should equal zero for a non-fault condition. The motor stator and battery case temperatures should be monitored for high stator or high battery case temperatures. Electromagnetic interference (EMI) will be an issue with heavy HEVs because of the higher power requirements of the elective drive system. See Sect. 5.2 for additional information concerning electric drive system faults. 


\section{DISCUSSION OF UNIQUE VEHICLE DESIGN FEATURES}

This section of the report addresses the major differences in equipment and systems between the design of a heavy HEV and of a conventional heavy vehicle. These major differences are the CNG fuel system for the ICE and the electric drive system. The electric drive system will include battery packs, inverter, electric motor, and associated cables and wiring. The battery pack will supply a nominal voltage of approximately $600 \mathrm{~V} \mathrm{dc}$ to the inverter. The weight of a heavy HEV is assumed to be about 3000 to $4000 \mathrm{lb}$ more than that of a conventional heavy vehicle. A conventional heavy vehicle weighs $10,000 \mathrm{lbs}$ or more.

\subsection{CNG FUEL SYSTEM}

National Fire Protection Association (NFPA) 52, Compressed Natural Gas Vehicular Fuel Systems Code, is the primary source of codes and regulations for the design and installation of CNG fuel systems on vehicles. This report assumes that the requirement of NFPA 52 is followed and the description of the CNG fuel system is based in NFPA 52.

A CNG system will supply fuel to the ICE. The CNG will be stored (at approximately 3000 psi) in high-pressure cylinders that are interconnected by a manifold. Current CNG tanks are rated at 3600-psi maximum operating pressure, but testing is in progress for tanks with up to 10,000 psi maximum operating pressure. The ICE will utilize spark ignition engine technology to ignite the CNG/air mixture in the ICE. Each CNG cylinder (container) will have a dedicated pressure relief device (PRD) and a container shutoff valve. The CNG fuel system will have a shutoff valve downstream from the container shutoff valve that can isolate all CNG containers from the rest of the CNG fuel system. The CNG system will also have an automatic shutoff valve that closes to interrupt CNG flow if the ICE stops for any reason. The CNG system will have a pressure regulator that reduces the fuel supply pressure to the pressure required by the ICE and a check valve to prevent gas from flowing back to the CNG fill connection.

NFPA 52 requires that certain fuel system components be listed, such as equipment and materials that meet identified standards or that have been tested and found suitable for the specified task. These systems and components include (1) PRDs (including relief valves), (2) valves, (3) pressure regulator, (4) pressure gauges, (5) hose and hose connections, (6) vehicle fueling connections, (7) engine fuel systems, and (8) electrical equipment related to $\mathrm{CNG}$ systems. ${ }^{1}$

\subsubsection{CNG Cylinder Design Considerations}

A CNG cylinder typically has a cylinder-shaped sidewall section with hemispherical domes on the ends. CNG cylinders are made of thick-walled, high-strength materials such as steel, aluminum, or composites to withstand the high-pressure forces that gas exerts on the walls of the cylinders. They are designed to withstand much higher pressures than the normal service

pressure. While cylinders are designed with a factor of safety that is typically greater 
than two, they should never be pressurized above their maximum fill pressure (generally 1.25 times service pressure). ${ }^{2,3,4}$

Each fuel supply container should be mounted in a location that would minimize damage from a collision. No portion of the fuel supply container or container accessory should be located ahead of the front axle or behind the point of attachment of the rear bumper to the vehicle. No portion of the fuel supply container or container accessory should protrude beyond the sides or top of the vehicle at the point where it is installed. Container valves should be protected from physical damage using the vehicle structure, valve protectors, or a suitable metal shield. The fuel system should be installed with as much road clearance as practical, but with not less than the minimum road clearance of the vehicle when loaded to its gross vehicle weight rating. If a shield is used to protect the fuel supply container, the shield should not contact the container or trap material that could damage the container. The container weight should not be supported by a fuel system component. Metal clamping bands and their supports should not be in direct contact with a container. A mounting system should minimize fretting corrosion between the container and the mounting system. The neck of the container and all CNG fittings within the passenger compartment should be enclosed in a gas-tight enclosure that is vented directly to the outside of the vehicle. ${ }^{1}$

There are four types of cylinder designs. The Type 1 cylinder is an all-metal constructed design. By replacing metal with lighter-weight composite materials, Type 2, 3, and 4 designs reduce the cylinder weight (discussed in detail later in the report). A composite cylinder is constructed of high-strength fibers that are wrapped around a cylinder liner and bonded together by a resin such as epoxy. This combination of fibers and resin can be extremely strong. ${ }^{2,3,4}$

The role of the metal and/or composite in each of the four designs can be understood by considering the portion of the pressure forces supported by each. This is also important in understanding the critical structural part in each design. In the Type 1 design, the metal supports $100 \%$ of the internal gas pressure since there are no composite materials. Metal supports approximately $55 \%$ of the load and composite supports about $45 \%$ in the Type 2 cylinder design. The composite supports about $80 \%$ of the internal pressure in the Type 3 cylinder design. In the Type 4 design, the composite wrap supports all of the gas pressure. ${ }^{2}$

\subsubsection{Type 1 cylinder design}

All-metal cylinders (i.e., Type 1) are constructed from either steel or aluminum alloys. Type 1 cylinders are the type most commonly used for CNG storage in natural gas vehicles (NGVs) because the properties of metals are well understood. Steel cylinders have the longest NGV service history, having been used since the 1940s. Steel cylinders are typically inexpensive and durable, but heavy. With steel and aluminum, a wide range of mechanical and physical properties of products can be obtained by controlling the chemistry, processing, and thermal treatments. Type 1 cylinders are generally safer than composite-based designs because all-metal cylinder designs are highly resistant to external damage.

All-steel cylinders for natural gas vehicles in the United States are manufactured using American Iron and Steel Institute (AISI) 4130X low-alloy steels. Steel offers the best 
resistance to fire effects, typically surviving twice as long as other designs when exposed to the standard bonfire test. Steel is generally safer than aluminum because of its superior impact and fire performance. All-steel cylinders have the highest melting point compared with other cylinder designs. Steel is an excellent conductor of heat to activate a PRD. It is estimated, based on service history, that steel cylinders will have a minimum 20-year life in $\mathrm{CNG}$ applications. Problems with steel cylinders have historically been due to manufacturing defects. Non-destructive examination requirements and good quality control have almost eliminated the risk of early failures in steel cylinders. The fabricated all-steel cylinder is heattreated by quenching and tempering to achieve the desired strength, hardness, and toughness. ${ }^{2,3}$

All-aluminum cylinders for NGV application are typically manufactured using Aluminum Association (AA) 6061-T6 aluminum-magnesium-silicon alloys. Higher-strength aluminum alloys are being considered. Aluminum alloys are attractive for a wide range of applications because of their physical and mechanical properties. In addition, aluminum is lightweight and fairly easy to fabricate. Because aluminum has a lower tensile strength than steel, the walls of an aluminum cylinder are thicker.

To avoid problems with the Type 1 cylinder design, Type 1 cylinders should be painted and the aluminum should not contact another metal, to prevent galvanic corrosion. Surface corrosion of steel or galvanic corrosion of aluminum can produce rusting or pitting. This surface corrosion can reduce the wall thickness of the cylinder and can result in cylinder failure. The depth of the pitting should be determined and the cylinder should be removed from service if the depth of the corrosion or pitting exceeds the allowable depth. Light corrosion can be cleaned and repainted.

Fire or heat can damage all cylinder types. Locating a cylinder too close to a heat source (such as an exhaust pipe) without providing a heat shield is a potential problem. Heat damage is normally evident as a region of discoloration on the cylinder surface. If heat damage is suspected, the cylinder should be removed from service.

Most metals suffer fatigue cracking when the metal is subjected to a large number of pressure cycles. This type of cracking generally occurs on the interior of the cylinder and is difficult to detect. Cylinders should not be used beyond their designed service life.

There have been no reported failures of Type 1 NGV cylinders in the United States since 1976, but worldwide there have been about 10 tank failures (i.e., ruptures). These worldwide problems have been addressed in current CNG standards by requiring the use of PRDs in the same compartment as the cylinder, requiring the use of a recognized quality system, and requiring the production (non-destructive) inspection of each cylinder (i.e., hardness testing, ultrasonic scanning, and hydrostatic proof testing). ${ }^{2,3}$ 


\subsubsection{Type 2 cylinder design}

Type 2 cylinders have a metal liner reinforced with hoop-wrapped continuous filaments in a resin matrix. In Type 2 cylinder designs, the metal liner can contain the maximum fill without the hoop-wrap (1.25 times service pressure). This design allows the use of higher fiber stress levels than are used in full-wrapped designs. The design of hoop-wrapped cylinders is based on the fact that a sphere will contain twice as high a pressure as a cylinder of the same diameter and wall thickness. Hoop-wrapping the weaker cylindrical portion of the vessel increases the pressure-retaining capability of the cylindrical portion of the vessel to that of the nearly hemispherical bare metallic end. Once the hoop wrapping has been applied to the metal liner, an autofrettage cycle is performed. During autofrettage, the cylinder is pressurized hydraulically to a pressure such that the liner is permanently expanded and placed in compression by the applied tension of the composite over-wrap. As a result of autofrettage, the fatigue performance of the cylindrical portion of the metal liner is increased. $^{2}$

Hoop-wrapped designs are generally safer than full-wrapped designs because of the redundancy of the liner design. E-glass has been commonly used in this type of cylinder, but new designs, based on carbon fibers, are being developed. The liner may be fabricated using AISI 4130X low-alloy steels or AA 6061-T6 aluminum alloys. The aluminum hoop-wrapped design was introduced to NGV service in the United States in 1982, and the steel hoopwrapped design was introduced in $1984^{2}$

There have been two reported failures of the Type 2 cylinder design in the United States, and both were of the aluminum hoop-wrap design. The failures were due to gross degradation of the composite overwrap together with over-pressurization of the cylinder. ${ }^{2}$

Surface corrosion of exposed metal domes in Type 2 cylinders can produce rusting or pitting, resulting in reduced wall thickness and eventual cylinder failure. Correct practice is to paint any exposed metal. Fatigue cracking of the metal liner due to the large number of pressure cycles can occur in this type of cylinder.

Surface abrasion or cuts can damage the composite and reduce the strength of the cylinder portion of the container. A cylinder should have a detailed visual inspection if there is evidence of abrasion/scuffing damage or a surface cut. Stress corrosion cracking (SCC) can take place in fiberglass composites (as a result of a combination of stress and a corrosive vapor or liquid). The worst corrosives are acids such as battery acids, but SCC can also occur when the cylinders are subject to very strong bases. ${ }^{2}$

\subsubsection{Type 3 cylinder design}

Type 3 cylinders are full-wrapped cylinders consisting of a metal liner that is wrapped with continuous filaments in a resin matrix. The composite wrap provides most of the containment strength. The long-term integrity of the composite in a Type 3 cylinder design is more critical to the cylinder's durability and safety than in the Type 2 cylinder design. The metal liner is presently manufactured using AA 6061-T6. These containers have seen less than 10 years of 
service with NGVs. The Type 3 cylinder design has advantages compared with the Type 4 designs because the metal liner is resistant to leaks and liner-boss interface concerns. ${ }^{2}$

There have been four reported failures of Type 3 fiberglass-wrapped cylinders in the United States, and SCC of the glass fibers is suspected to be the primary cause of these failures. A cylinder should have a detailed visual inspection if there is evidence of abrasion/scuffing damage or a surface cut, since these conditions can reduce the strength of a cylinder. SCC can occur in fiberglass composites as a result of a combination of stress and a corrosive liquid. Fire or heat can damage all cylinder types. ${ }^{2}$

\subsubsection{Type 4 cylinder design}

Type 4 cylinders are full-wrapped cylinders with a gas-tight plastic liner that is non-loadbearing. The composite, usually a carbon-fiber-wrapped material, bears the entire load. The durability of the composite determines the safety and durability of the cylinder. The plastic liners may be manufactured in a number of ways; rotational molding or extrusion are two of the processes used. The Type 4 design is attractive because it is the lightest weight of all designs.

There has been one failure of a Type 4 cylinder design, probably due to impact damage. There have also been several cases of leaking in Type 4 cylinders due to plastic liner defects. ${ }^{2}$

Carbon fibers have many favorable attributes, such as high strength and resistance to environmental attack. However, Type 4 carbon fiber cylinders are sensitive to impact damage - the brittle fibers can break when subjected to impact events such as dropping or being struck by road debris. When a Type 4 carbon fiber cylinder suffers impact damage, it may be difficult to see this damage. A cylinder should have a detailed visual inspection if there is evidence of abrasion/scuffing damage or a surface cut. ${ }^{2}$

\subsubsection{PRDs and Venting Systems for PRDs}

Each CNG cylinder should have at least one PRD. The PRD should be in direct communication with the fuel and should be vented to the atmosphere by a method that can withstand the maximum pressure that can occur. The PRD should be sized to protect the fuel container from the excessive pressures caused by exposure to fire or other heat source (worstcase conditions). The PRD should be located so that the PRD and the cylinder are at the same temperature. The PRD should be tested at least every 5 years. ${ }^{1}$

When located in a vehicle compartment capable of accumulating natural gas, the container should have a PRD that vents to the outside of the vehicle. The vent line should have no diameter less than the outlet diameter of the PRD and should be constructed of metallic tubing. The discharge line should be vertically oriented, and the line should be secured at intervals to minimize damage to or failure of the line. The outlet of each vent line should be protected by caps, covers, or other means to keep water, dirt, and insects from collecting in the line. These protective devices should not restrict the flow of gas. ${ }^{1,5}$ 


\subsubsection{Shutoff Valves}

Each fuel cylinder (container) should be equipped with a dedicated container shutoff valve (i.e., one shutoff valve for each container). There should also be a shutoff valve that allows isolation of all fuel containers from the remainder of the fuel system (i.e., one shutoff valve for all containers). The valve that isolates all containers should be downstream of the container shutoff valve. The shutoff valves can be manual or normally closed, automatically actuated shutoff valves. A valve that automatically prevents the flow of fuel to the engine when the engine is not running should also be provided in the system. The engine shutoff valve should be downstream of the shutoff valve for all containers. Electronic fuel injectors are considered to be automatic valves. ${ }^{1}$

\subsubsection{Check Valve}

The fuel system should be equipped with a backflow check valve that prevents return flow from the containers to the filling connection. The check valve should not hinder the fueling of the vehicle.

\subsubsection{Pressure Regulator}

The fuel system should have automatic pressure-reducing regulators installed to reduce the fuel pressure to the level required by the gas-air mixer. A means should be provided to prevent regulator malfunction due to refrigeration effects. The attached fuel lines should not support the weight of the regulator. The inlet and each chamber of a pressure regulator should be designed for its service pressure and should have a pressure safety factor of at least four. ${ }^{1}$

\subsubsection{Pressure Gauge}

The vehicle should be equipped with a pressure gauge that provides an accurate pressure readout. The pressure gauge should be designed so that a significant leak path would not be created if it were damaged or broken. The pressure gauge should be monitored to detect any sudden or unexpected change in pressure (other than filling).

\subsubsection{Fuel System Piping}

Fuel lines should be mounted and supported to minimize vibration and should be protected against damage, corrosion, or breakage due to strain, wear, expansion, or contraction and against any loosening while in operation. Materials (pipe, pipe thread jointing material, etc.) should be compatible with natural gas. Joints and connections should be located in accessible locations. Fuel lines that pass through a vehicle support structure or panel should be protected by grommets or similar devices. Fuel lines should have the maximum practical clearance from the engine exhaust system. Fuel line components in the engine compartment should be designed or selected for service for a temperature range of $-40^{\circ} \mathrm{F}$ to $250^{\circ} \mathrm{F}$. All 
other components should be designed or selected for a range of $-40^{\circ} \mathrm{F}$ to $180^{\circ} \mathrm{F}$. Aluminum or copper pipe, tubing, or fittings should not be used between the fuel container and the firststage pressure regulator. ${ }^{1,6}$

\subsection{ELECTRIC DRIVE PROPULSION SYSTEM}

The heavy HEV will have an electric drive system that is powered by much higher voltage and power levels than those used in conventional vehicles. The vehicle will have battery packs that will supply dc voltage and current to the power converter (i.e., inverter). The inverter will convert the dc voltage to 3-phase ac voltage and supply the needed ac currents to a traction motor. The inverter and traction motor will be rated for continuous operation typically in the 150 - to 250 -kilowatt $(\mathrm{kW})$ range. Between the batteries and the inverter will be automatic disconnects (i.e., contactors) that can isolate the battery voltage from the electric drive system. The battery voltage will be isolated when the vehicle is not in operation or when certain fault conditions are detected.

\subsubsection{Battery Bank}

Battery packs will produce the electrical energy required to drive the traction drive motor. Battery packs for a heavy HEV will supply approximately $600 \mathrm{~V} \mathrm{dc}(\mathrm{Vdc})$ to the inverter. The battery packs will be electrically isolated from the conductive structure of the vehicle. Tamper-proof covers will be needed on the battery compartment to reduce the probability of electric shock due to inadvertent access.

Some of the battery types that are being considered for HEV use are lead-acid, sealed leadacid, nickel cadmium, nickel metal hydride, lithium polymer, lithium ion and others. Since HEVs require high-power batteries, these battery types are the leading candidates. Each of these battery types has different health and safety issues associated with its design. The main safety concerns associated with batteries are the electrical, chemical, and thermal hazards;

but the vehicles themselves must also be safe to operate and be crashworthy. ${ }^{7,8,9,10}$

Lead-acid batteries are a likely near-term option for heavy HEVs because lead-acid batteries offer high power output and fairly low cost. Batteries are constructed of cells that include an electrolyte and two electrodes, one negative and one positive. In a lead-acid battery, the electrolyte is a solution of sulfuric acid in water. When a battery is connected to an external load, a chemical reaction takes place that converts the chemical energy to electrical energy; current flows from the positive electrode through the load and back to the negative electrode. When a battery is charged, a strong acid is created at the electrode surfaces. Overcharging a battery will result in corrosion of the electrodes and will result in loss of the electrolyte if the battery is vented. ${ }^{9,10}$

The danger and risks of lead-acid batteries are widely known and are well characterized. Lead-acid batteries are relatively safe as long as proper precautions are taken. Small amounts of hydrogen and oxygen are produced at the electrodes during normal battery operation. If the battery is vented (open), the hydrogen and oxygen are vented to the atmosphere. If the battery is sealed (or valve-regulated), the hydrogen and oxygen are recombined into water. 
Overcharging can result in the buildup of hydrogen, and fire is a possibility if the battery compartment is not adequately ventilated. ${ }^{9,10}$

Battery capacity is normally measured at $20^{\circ} \mathrm{C}$, the temperature at which performance is optimum. Temperatures of less than $20^{\circ} \mathrm{C}$ will slow the chemical reaction and reduce the capacity of a battery cell. Higher temperatures do not reduce the capacity of a battery, but each $10^{\circ} \mathrm{C}$ rise in temperature above $20^{\circ} \mathrm{C}$ will double the corrosion rate of the electrodes and reduce the battery lifetime significantly. Monitoring the state of charge of the battery group and maintaining a proper charge level without overcharging is an important battery life issue. A smart battery charging system is generally required for the vehicle. ${ }^{9,10}$

\subsubsection{Power Inverter}

An inverter will be used in an HEV to convert the dc voltage supplied by the batteries to ac voltages and currents required by the electric drive motor. The inverter consists of five main subsystems: power switches, controller, gate drivers, filter components, and sensors. The controller (typically a low-voltage device that uses 5-V logic) compares the output of the power processor unit with the desired value and provides a signal to the gate drivers controlling the state of the power switches. The controller also monitors various sensors and inhibits operation of the inverter if certain out-of-specification conditions are determined. These out-of-specification conditions include high or low battery voltages and currents, power switch faults (i.e., over-current, over-temperature, and over-voltage conditions), and motor current imbalance. Gate drivers convert the 5- $\mathrm{V}$ signal from the controller to a highervoltage signal (15-V) to control the state of the power semiconductors (i.e., switches). The gate drivers provide isolation (i.e., optocoupler) between the low-voltage circuits of the controller and the high-voltage circuits of the power switches. The isolation will prevent a problem with a high-voltage circuit from affecting the low-voltage circuits in the controller. The power semiconductors change states to process the output of the inverter to the desired characteristic needed by the electric drive motor. The power semiconductors module is either mounted to the heat exchanger or is an integral part of the heat exchanger. The heat exchanger provides the required cooling of the power semiconductors. Sensors (current and voltage) provide information to the controller. The inverter will have a bus structure to conduct motor currents between the power components of the inverter. The bus structure will conduct current from the dc bus to the filter capacitors, power switches, and motor. The inverter will have filter capacitors to carry the high-frequency pulse width modulated (PWM) currents and act as snubbers to limit turn-off voltage spikes across the power switches.

Power flow through an inverter can be reversed. The controller will inhibit charging of the vehicle battery bank when the batteries reach the maximum voltage level. Current flow capability in the reverse condition should be compared with the forward direction.

Advances in semiconductor fabrication technology have made it possible to significantly improve the voltage and current-carrying capabilities and the switching speeds of the power semiconductor devices. The goal for an inverter is to minimize the losses due to the cost of lost energy (i.e., operate at high efficiency) and the difficulty in removing the heat generated from the dissipated energy. The high efficiency that is desired for power conversion cannot 
be achieved by operating the power devices in their linear (active) region where the power device is operated as an adjustable resistor to regulate the voltage output. Operating an inverter in the linear mode will result in an efficiency that is less than $80 \%$. If the inverter is designed so that the power devices operate in the switch mode (like an ideal switch, either fully on or off), it converts the dc voltage to an ac voltage at the desired switching frequency. The desired output voltage can be obtained by controlling the duty ratio of the switching device. The duty ratio is the ratio of the "on" time to total time, where total time is "on" time plus "off' time. Efficiencies of 95\% (or greater) can be achieved when an inverter is designed to operate in the switch mode. Because the power device operates as a switch in the switch mode, the power loss due to conduction is minimized. The power loss due to switching is proportional to the switching frequencies. ${ }^{12}$

\subsubsection{Electric Drive Motor}

The electric drive motor for the HEV will be a three-phase ac electric motor. A highefficiency induction motor would be a likely choice for a heavy HEV because induction motor technology is well understood, reliable, and rugged. Efficiency of $90 \%$ or higher could be achieved with a 150- to 250-horsepower induction motor. The motor must be able to operate at high efficiencies over a fairly wide speed and torque range. The motor will require sensors that can monitor motor currents and the temperature of the stator windings. These sensors (current and temperature) will provide information to the controller. ${ }^{13}$

The use of a PWM inverter to drive the motor generates large repetitive pulses and will require that the motor be inverter-grade to tolerate the electrical stress on the insulation system. The waveforms generated by fast switching of the power devices can produce rapid changes in voltage that are two to three times the dc bus voltage. These voltage levels will stress the different types of insulation materials present in the motor winding.

The motor will require liquid cooling and must be able to operate over a fairly wide range of inlet coolant temperatures. The noise level generated by the motor must be within an acceptable range to be tolerated by the vehicle occupants.

\subsubsection{Automatic and Manual Disconnect}

The vehicle should contain an automatic disconnect (i.e., contactors) and a manual disconnect to provide the ability to isolate the electric drive system from the battery voltage. The automatic disconnect will be the primary and the manual disconnect will be the backup way to isolate the battery voltage. The automatic disconnect should normally be open and should close when the vehicle is started with the key switch and the voltage of the inverter reaches a determined precharge voltage level. The contactors should open when the key switch is turned off or when a potentially unsafe condition is detected. The automatic disconnect should be located close to the battery output terminals to minimize the external circuitry, which is not de-energized when the automatic disconnect opens the circuit.

The manual disconnect provides a manual means to isolate the battery voltage from the electric drive system. The manual disconnect should be used when maintenance is being 
performed on the electric drive system and could be used following a vehicle crash. The manual disconnect should be a single-pole device that is easy to access, well marked, and in a common location, such as the area beneath the driver's seat.

\subsubsection{Electric Drive Wiring}

The electric drive system will have wiring assemblies (cables) to connect the battery output terminals to the contactors, the contactors to the inverter, and the inverter to the motor. The cables' insulation should be rated for the voltage level and designed for use in a highway vehicle environment. The cables' conductor should be rated for the ampere level that will be associated with an electric drive system application. Connectors for the cables should be designed to withstand the vibration, stress, and strain of highway applications. Electric drive cables should be protected by grommets when they pass through a structural support or panel.

\subsubsection{Sensors}

The vehicle will have several sensors (e.g., current, voltage, temperature) to monitor conditions with the vehicle and electric drive system and provide input to the electric drive system and vehicle monitoring system. Isolation of the battery voltage (actuation of automatic disconnect) may be appropriate if one of the following conditions is detected: excessive electric drive system current, a ground fault, actuation of the vehicle crash sensor, opening of a hazardous voltage interlock, or low battery voltage. The electric motor should have a temperature sensor or other means to monitor the stator winding temperature. The battery compartment should have a temperature sensor and a hydrogen sensor.

\subsection{CONDITION MONITORING SYSTEM}

A system that has the ability to monitor the condition of key equipment and make smart decisions concerning when to repair or replace components in key equipment should be considered for this vehicle. This technology is known as condition-based or predictive maintenance. Condition-based maintenance or predictive maintenance is a powerful technique because it enables the systematic monitoring (while on-line) and trending of the condition of equipment. Condition-based maintenance provides early warning of equipment operation that is approaching out-of-limit conditions. Since parameters of key equipment items are being monitored, corrective actions can typically be taken before the equipment fails. The frequency of catastrophic failures, which can produce expensive secondary damage, can also be reduced. Equipment failures can produce safety-significant events that have costs (i.e., injury and loss of life) and negative publicity that far exceed the costs associated with monitoring, replacing, and repairing the equipment. Knowing the condition of equipment enables the operator to plan and carry out repairs and maintenance actions when the equipment is not required to be in service. Maintenance activities can then be more effectively planned from the standpoint of manpower, tools, and parts.

It has been estimated that U.S. industry spends over $\$ 200$ billion per year to maintain plants and equipment. Techniques that can more effectively focus these maintenance expenditures 
are of great interest to U.S. industry. Condition-based or predictive maintenance has received a great deal of attention in the last decade because of its potential to direct maintenance personnel to equipment that needs maintenance. According to some studies, predictive maintenance can be more cost-effective than corrective maintenance (repairing equipment when it breaks down) or preventative maintenance (repair at scheduled intervals such as 50,000 miles). Today's technology, high-speed computers, and sophisticated monitoring equipment have made it possible to have a reliable and cost-effective condition-based maintenance program.

A condition-based monitoring system should monitor the condition of key equipment in the CNG fuel system and the electric drive system with the objective of taking any needed maintenance actions prior to the failure of the equipment. Equipment in the $\mathrm{CNG}$ fuel system would be monitored for loss of CNG containment. The $\mathrm{CNG}$ fuel system should be monitored for pressure changes that would indicate a leak. The CNG isolation valves should be periodically operated to verify their ability to change states. The PRDs should be tested periodically to verify their ability to open, and the PRD vent lines should be inspected for obstructions and for verification that they discharge to the exterior of the vehicle (away from ignition sources).

The electric drive system is an excellent candidate for condition monitoring. The dc voltage, current, and temperature of the battery packs should be monitored. The battery voltage should be monitored for high and low voltage levels, the current should be monitored for over-current conditions, and the sum of the dc currents should be equal to zero (no-fault condition). The motor voltages and currents should be monitored for imbalance, and the sum of the motor currents should be zero. The efficiency of the inverter and motor could be monitored and action could be taken if there were a noticeable change. The battery compartment should be monitored for electrolyte spillage, buildup of gases, and ambient temperature.

A typical condition-based monitoring system will contain a microprocessor-based data collector, a host computer, software, and transducers. The data acquisition system and a host computer will remove the possibility of human error during data input, reduce manpower requirements, and automate the data handling as much as possible. The system should be capable of collecting, storing, comparing, and presenting data in a variety of formats. For example, vibration data could be presented in the following formats: displacement, frequency, velocity, and acceleration. Vibration analysis, fluid analysis (for wear particulates), thermal analysis, and electric motor analysis have been used with great success. ${ }^{14}$

Electrical signature analysis (ESA) is a powerful and versatile technology, pioneered by Oak Ridge National Laboratory, that is a subset of condition-based monitoring. This technology can be integrated in most electro-mechanical equipment to enhance monitoring capabilities and should be considered for the electric drive system. ESA provides diagnostic and prognostic (predictive) information comparable to conventional vibration analysis, but requires access only to electric lines carrying input and output power, rather than to the equipment itself. Time-dependent load and speed variations in electro-mechanical systems 
generally induce small variations in the motor's electrical response. These variations are observed as a change in current for an electric motor and changes in voltage for a generator. Comparing the electrical response (i.e., signature) of an electro-mechanical system that has operated for a significant period of time (and thus has the potential for degradation and wear) with the electrical response when the system was new can identify differences. ESA techniques can analyze these differences and match them to their sources. The resulting time and frequency signatures reflect load, stresses, and wear throughout the system and allow an extensive range of mechanical diagnostic information to be obtained. ESA techniques can be used to pinpoint electrical and mechanical problems and target maintenance on an as-needed basis, thereby increasing reliability and maintenance efficiency and minimizing unexpected downtime. $^{14}$ 


\section{PROPERTIES OF GASES AND MATERIALS}

\subsection{NATURAL GAS AND COMPRESSED NATURAL GAS}

\subsubsection{Natural Gas Properties}

Natural gas is one of the world's most abundant fossil fuels, supplying about $25 \%$ of the energy demands in the United States. Natural gas is produced from gas wells or in conjunction with crude oil production. The primary uses of natural gas in the United States are for space heating, electricity generation, and industrial processes. Most of the natural gas consumed in the United States is domestically produced. Natural gas is a very good sparkignition ICE fuel and was used as a fuel in the early days of engine development. It is attractive as a fuel for vehicles because it is clean-burning, with low carbon monoxide emissions, and has practically no particulate matter emissions. National goals for both energy security and clean air have resulted in heightened interest in the use of natural gas in the transportation market. ${ }^{15}$

The content of natural gas as delivered through the pipeline system varies fairly widely. For example, the composition of methane $\left(\mathrm{CH}_{4}\right)$ in natural gas pipelines may vary from 80 to 95\%. The natural gas in the pipeline system also contains other hydrocarbons, such as ethane and propane, as well as nitrogen, helium, carbon dioxide, hydrogen sulfide, and water vapor. In its pure state, natural gas is colorless, odorless, and tasteless. For safety reasons an odorant, Mercaptan, is added so that a leak can be detected. Methane is a gas at temperatures greater than $-161^{\circ} \mathrm{C} .^{16}$

Methane is a very light gas with a specific gravity of 0.55 . The physical properties of methane are often used when comparing the properties of natural gas with those of other fuels. The specific gravity of natural gas is typically listed as 0.6.

The air-to-fuel ratio indicates the amount of air relative to the amount of fuel used in combustion. The stoichiometric ratio is the minimum amount of air relative to fuel needed for complete combustion. The stoichiometric ratio for natural gas (and other gaseous fuels) is normally indicated by volume and should not be confused with the weight ratio used for liquid fuels such as gasoline. The air-to-natural-gas stoichiometric ratio by volume for complete combustion is $9.5: 1$ to $10: 1$. The stoichiometric ratio by weight for natural gas is about $17: 1$, which can be compared with a ratio of 14.7 for gasoline. ${ }^{15}$

The two properties of natural gas that affect safety are the auto-ignition temperature and the flammability limits range. The auto-ignition temperature (also known as ignition temperature) is the lowest temperature at which a substance will ignite because of heat alone, without an additional spark or flame. The ignition temperature of natural gas varies with fuel composition, but it is always lower than that of pure methane. The estimated auto-ignition temperature of natural gas is about $540^{\circ} \mathrm{C}\left(1004^{\circ} \mathrm{F}\right)$. A combustion engine using spark ignition will ignite the natural gas-air mixture at a higher temperature to ensure combustion; 
the ignition temperature will be in the range of $593-649^{\circ} \mathrm{C}\left(1100-1200^{\circ} \mathrm{F}\right)$. The range of flammability is the upper and lower percentage of a gas in an air-fuel mixture within which the mixture can burn or explode. The flammability limits for natural gas are approximately 5 to $15 \%$ volume concentrations. Methane flames are visible under all conditions, so they are easy to detect. ${ }^{15,16}$

\subsubsection{Compressed Natural Gas Properties}

To be used as a fuel for vehicles, natural gas must be compressed (or liquefied) to decrease the storage volume requirements. Three common pressures for CNG are 2400, 3000, and 3600 psi. For these three pressures, the equivalent amount of energy stored per unit volume is 22,27 , and $33 \%$ of that of gasoline, respectively. Because CNG cylinders have thicker walls than gasoline tanks, a smaller amount of fuel can be stored within a given tank volume. CNG fuel systems deliver fuel to the ICE as a result of the stored pressure in the fuel tank. There are no fuel pumps or compressors. As CNG moves from the tanks to the engine, its pressure is reduced in steps to a pressure that is slightly above atmosphere. ${ }^{15}$

Fuel stored at high pressure presents some unique handling considerations. For CNG, two of these are the Joule-Thompson effect and static electricity. The Joule-Thompson effect is important because in CNG fuel systems, natural gas undergoes a rapid decrease in pressure and temperature as it moves through the fuel system. The cooling effect is most pronounced with the pressure drops associated with fittings and pressure regulators. The presence of water vapor and compressor oil in the CNG can cause problems because water vapor and sulfur combine to form hydrates in the fuel system where Joule-Thompson cooling occurs. Hydrates are crystalline in structure and can obstruct the fuel lines. Localized heating of fuel line components may be required to prevent obstructions. ${ }^{15}$

Precautions must be taken to dissipate any static electrical charge (characterized by high voltage and low current) prior to the transfer of natural gas (both fueling and removal of fuel from a vehicle) to reduce the possibility of a spark ignition event. A grounding strap is used to make sure that the vehicle being fueled (or having fuel removed) and the fueling piping are at the same electric potential. ${ }^{17,18}$

A CNG leak can quickly produce a large gas/air mixture volume. A unit volume of CNG at 3000 psi will expand by approximately 200 times when released into the atmosphere. The ignition energy required is in the range of 0.15 to $0.30 \mathrm{~mJ}$. There is a danger of ignition if a CNG leak occurs because a portion of the gas/air mixture will be within the flammable range and an ignition source may be present. ${ }^{15,16}$

The fact that the natural gas is stored at a high pressure for use as a vehicular fuel is the most unique physical characteristic of $\mathrm{CNG}$. The presence of a gas that is stored and transferred at pressures that far exceed the normal experience of most fleet operations personnel raises the standard of precaution and training required. Inadvertent opening of valves or loosening of fittings containing high-pressure natural gas not only can create a fire hazard, but also can result in the high-velocity ejection of metal parts or fragments that could be lethal to nearby personnel. ${ }^{15,16}$ 


\subsubsection{Comparison of CNG with Gasoline and Diesel Fuel}

Gasoline and diesel fuel are the two most common fuels used for vehicles. This section of the report discusses these two fuels and compares their properties with those of CNG. Gasoline is the most common fuel for vehicles on the highway. The same properties that make gasoline a very good spark ignition fuel also make it very dangerous. Gasoline will change from a liquid to a gas (i.e., reach a flash point) at temperatures as low as $-45^{\circ} \mathrm{C}$. If not contained, gasoline will evaporate over a period of time and present an ignition hazard. The flammability limit of gasoline vapor varies between 1.4 and $7.6 \%$ by volume. These flammability limits make gasoline an efficient fuel. Gasoline has a low ignition temperature (i.e., an auto-ignition temperature of approximately $257^{\circ} \mathrm{C}$ ). A spark developed by static electricity can easily ignite gasoline vapors. Gasoline vapors are heavier than air and will pool in low spots. Spilled gasoline (liquid or vapors) can settle in drains, pipes, and sumps and be ignited under favorable conditions. Gasoline flames are visible under all conditions. ${ }^{15,16}$

Diesel fuel is much safer than gasoline, but it can be dangerous under certain conditions. Diesel fuel is classified as a combustible liquid because it must be heated to about $74^{\circ} \mathrm{C}$ in order to vaporize to form a flammable mixture. Often a diesel fire occurs when diesel fuel is spilled onto a hot surface, such as an exhaust manifold. A hot surface will vaporize and ignite the diesel fuel. A high-pressure leak will vaporize the diesel fuel, and a vaporized fuel-air mixture can be ignited by an ignition source. The auto-ignition temperature for diesel fuel is $316^{\circ} \mathrm{C}$, and the flammability limits are 1 to $6 \%$ by volume in air. Diesel fuel flames are visible under all conditions. The energy content, lower heating value, of gasoline and diesel is $30-33 \mathrm{MJ} / \mathrm{L}$ and $35-37 \mathrm{MJ} / \mathrm{L}$ respectively. ${ }^{15,16}$

\subsubsection{Health Issues}

The principal constituents of natural gas - methane, ethane, and propane-are not considered to be toxic. These gases are considered asphyxiants because they can displace oxygen in a closed environment. The Occupational Safety and Health Administration has set a timeweighted average personal exposure limit of 1,000 ppm for propane. A number of minor constituents of natural gas threshold limit values (TLVs), are listed by the American Conference of Governmental Industrial Hygienists, including butane $-800 \mathrm{ppm}$, pentane $-600 \mathrm{ppm}$, hexane- $-50 \mathrm{ppm}$, and heptane $-400 \mathrm{ppm}$. The effective TLV for an average natural gas composition, considering all of these limits, is about $10,500 \mathrm{ppm}$. The odor threshold of odorized natural gas is about $10,000 \mathrm{ppm}$. Therefore, it is unlikely that personnel will be unknowingly exposed to the TLV concentration, since they can detect it by odor. $^{15}$

\subsection{COMPOSITE MATERIALS}

Composites, materials made of combined fibers and resin, are used in the reinforcement of high-pressure $\mathrm{CNG}$ cylinders because they are lightweight and provide high strength. Glass fibers are widely used because of their combination of mechanical properties and low cost. 
Two commonly used types of glass fibers are E-glass (calcium alumino-borosilicate glass) and S-glass (magnesium alumino-silicate glass). The tensile properties of glass fibers are reduced in the presence of water and/or under sustained static loads. Any surface flaw in the fibers deepens as a result of water leaching components from the surface. Under static loads, the growth of surface flaws is accelerated by the action of moisture from the atmosphere (i.e., SCC). S-glass fibers are less prone to SCC than E-glass fibers. ${ }^{2}$

In general, carbon fibers have the highest modulus and strength of all reinforcing fibers. Carbon fibers have high fatigue strength and do not suffer from stress corrosion or stress ruptures at room temperature. At elevated temperatures, the strength and modulus of carbon fibers are superior to those of other fibers. Disadvantages of carbon fibers include their higher cost, lower strain-to-failure rate, and lower impact resistance. Concern about the resistance of carbon fibers to handling damage has resulted in the practice of overlaying the carbon cylinder with a protective wrap of glass fibers. The high cost of carbon fibers has limited their entry into the market. ${ }^{2}$

The type and orientation of fibers determine the ultimate strength potential of the composite materials. The resin matrix dominates the actual level of properties realized by providing effective coupling and stress transfer efficiency. The resin properties determine overall composite performance with respect to high-temperature behavior, corrosion resistance, and flammability. Polyester or epoxy resin is used for the composite matrix. Epoxy resins offer superior physical properties and elevated temperature retention properties over polyester resins. $^{2}$

Plastic materials such as nylon or polyethylene are currently used for the cylinder liner. The use of Nylon 11 in the manufacture of gas pipe has fostered its use as a plastic liner in NGV cylinders. High-density polyethylene is used extensively as a material in natural gas distribution piping. The low cost and properties of high-density polyethylene make it a good candidate for NGV cylinder liners. ${ }^{2}$ 


\section{ELECTRIC SAFETY ISSUES}

A heavy HEV will have an electric drive system that operates at much higher voltage and current levels than today's heavy vehicles. Electric shock is the primary safety hazard for the electric drive system. The isolation of the voltages and currents associated with the electric drive system from conductive components of the vehicle and from the occupants of the vehicle is a major safety issue.

\subsection{ELECTRIC SHOCK}

The resistance of a substance to the flow of electricity is determined by three factors: the nature of the substance itself, the length and cross-sectional area (size) of the substance, and the temperature of the substance. Conductors (i.e., metals) offer very little resistance to the flow of electric current. Insulators, such as Bakelite, porcelain, and pottery, offer a high resistance that prevents the flow of electric current. In other substances, the resistance will vary with the amount of moisture that it contains. For example, wood has a high resistance when dry, but its resistance drops to the point where it will readily conduct electricity when it is saturated with water. The same thing is true of human skin. When it is dry, skin has a fairly high resistance to electric current; but when it is moist, there is a radical drop in resistance. ${ }^{19}$

Electricity travels in closed circuits, and its normal path is through a conductor. Electric shock occurs when a person becomes a part of the electric circuit. The current enters the body at one point and exits at another location. Electric shock normally occurs because a person contacts an energized phase (hot wire) and the ground.

The metal cases of electric tools and machines may become energized if there is an insulation failure (loss of isolation). The person using these tools and machines is made less vulnerable to electric shock when there is a low-resistance path from the metallic case of the tool or machine to the ground. The use of an equipment grounding conductor, a low-resistance wire that causes the unwanted current to pass directly to the ground, greatly reduces the amount of current available to pass through the body of the person in contact with the tool or machine.

The effects of electric shock depend upon several factors, including the type of circuit, and its voltage, resistance, current, pathway through the body, and duration of the contact. Shock effects can range from a barely perceptible tingle to immediate cardiac arrest. Although there are no absolute limits or even known values that show the exact injury from any given current, a difference of less than $100 \mathrm{~mA}$ exists between a current that is barely perceptible and one that can kill. Muscular contractions caused by electric stimulation may not allow the victim to free himself from the circuit, and the increased duration of exposure increases the dangers to the shock victim. For example, a current of $100 \mathrm{~mA}$ for 3 seconds is equivalent to a current of $900 \mathrm{~mA}$ applied for about .03 seconds in causing ventricular fibrillation. Low voltages can be extremely dangerous because the current levels can be lethal. ${ }^{20}$

Electric shock can be prevented by adhering to certain practices that will minimize the chance for electric shock. These practices are discussed in the following sections. 


\subsubsection{Insulation}

The insulation associated with electric drive system cables, power devices, and the motor is a design feature that is required for the component to function properly, and for safety reasons. Failure of this insulation can result in undesired high current paths and then failure of the electric drive system component.

Insulation is one way to safeguard individuals from electrically energized wires and electric components. Any material with high resistance to electric current is an insulator, and materials such as rubber, plastic, mica, and glass are placed on conductors to prevent electric shock, fires, and short-circuit faults. The insulation should be rated for the voltage levels applied to the component and for other existing conditions, such as temperature, moisture, oil, gasoline, or corrosive fumes. All these factors must be evaluated before the proper choice of insulation can be made. Conductors and cables are marked by the manufacturer to show the maximum voltage and American Wire Gage size, the type letter of the insulation, and the manufacturer's name or trademark.

\subsubsection{Guarding}

Electric equipment that operates at $50 \mathrm{~V}$ or higher should have any energized parts guarded to prevent accidental contact, because voltages of less than $50 \mathrm{~V}$ are not considered lethal. Guarding may be accomplished by locating the equipment in an enclosure accessible only to qualified persons. The enclosure containing exposed live parts must be marked with conspicuous warning signs forbidding unqualified persons to access energized components. The enclosure should have interlock switches that deactivate the circuit if the switches are opened. The battery compartment and any connector that will provide access to high voltages should be provided with guards. ${ }^{20,21}$

\subsubsection{Grounding}

Grounding is another method of protecting people from electric shock; however, it is normally a secondary protective measure. The "ground" refers to a conductive body (usually the earth or the frame of the vehicle); grounding means a conductive connection by which an electric circuit or equipment is connected to earth or the ground plane. Grounding does not prevent a person from receiving a shock or being injured or killed. It will, however, substantially reduce the possibility of such accidents, especially when used in combination with other safety measures. There are two kinds of grounds, the service or system ground and the equipment ground. The service or system ground is primarily designed to protect machines, tools, and insulation against damage. The equipment ground (equipment case or housing mounted on vehicle frame) safeguards the electric equipment operator in the event that a malfunction causes the metal case of an electric/electronic component or the metal frame of the tool to become accidentally energized. ${ }^{22}$

Grounding is intentionally creating a low-impedance path from a tool or electric system to the frame of the vehicle. When properly done, this ground path offers sufficiently low 
resistance and has sufficient current-carrying capacity to prevent the buildup of voltages that may result in a personnel hazard.

\subsubsection{Ground Fault Detection Circuit}

Ground fault detection circuits can be designed that will detect and provide a signal that the isolation between the battery voltage and the vehicle frame has been compromised. The midpoint of the dc link (battery) voltage can be referenced through a high impedance series resistor-capacitor (RC) circuit to the chassis of the vehicle. This RC circuit path can be monitored to detect loss of isolation of the battery voltage from the vehicle chassis. If there is a fault current from mid-point to the dc link to the chassis, then the capacitor will be charged and a voltage level can be detected across the capacitor; otherwise, the voltage will be zero. A resistor (five to ten Mohms) will limit the current flow. The detection circuit should be designed so that it provides a signal path to the vehicle's control circuit to indicate a loss-ofisolation fault for the dc link. ${ }^{23}$

\subsubsection{Circuit Protection Devices}

Circuit protection devices are designed to automatically limit or shut off the flow of electricity in the event of a ground-fault, overload, or short circuit in the wiring system. Fuses, circuit breakers, and ground-fault circuit interrupters (GFCIs) are three well-known examples of such devices. The bi-directional flow of current and the noise generated by PWM limit are two factors that limit the use of circuit breakers and GFCIs in heavy HEV.

Fuses and circuit breakers are over-current devices that are placed in circuits to monitor the amount of current that the circuit will carry. They automatically open or break the circuit when the amount of current flow becomes excessive and therefore unsafe. Fuses are designed to melt when too much current flows through them. Circuit breakers, on the other hand, are designed to trip open the circuit by electro-mechanical means. Fuses and circuit breakers are intended primarily for the protection of conductors and equipment. They prevent overheating of wires and components that might otherwise create hazards for operators. They also open the circuit under certain hazardous ground-fault conditions.

The GFCI is designed to shut off electric power within as little as 1/40 of a second. It works by comparing the amount of current going to electric equipment with the amount of current returning from the equipment along the circuit conductors. If the current difference exceeds approximately 5 to $10 \mathrm{~mA}$, the GFCI interrupts the current quickly enough to prevent electrocution. The GFCI is used in high-risk areas such as wet locations and construction sites. GFCIs are frequently tripped by the noise generated by PWM, which limits their potential use in HEV applications. ${ }^{20}$

\subsubsection{Safe Work Practices and Training}

Employees working with electric equipment need to use safe work practices. These include de-energizing electric equipment before inspecting it or making repairs, using appropriate 
protective equipment, using electric tools that are in good repair, and using good judgment when working near energized lines.

The accidental or unexpected sudden starting of electric equipment can cause severe injury or death. Before any inspections or repairs are made, the circuits should be deactivated at the switch box and the switch padlocked in the "off" position. At the same time, the switch or controls of the machine or other equipment being locked out of service must be securely tagged to show which equipment or circuits are being worked on.

Maintenance employees should be qualified personnel who have been well instructed in lockout procedures. No two locks should be alike; each key should fit only one lock, and only one key should be issued to each maintenance employee. If more than one employee is repairing a piece of equipment, each should lock out the switch with his or her own lock and never permit anyone else to remove it. The maintenance worker should, at all times, be certain that he or she is not exposing other employees to danger.

To ensure that they use safe work practices, employees must be aware of the electrical hazards to which they will be exposed. Employees must be trained in safety-related work practices, as well as any other procedures necessary for safety from electrical hazards.

Perhaps the single most successful defense against electrical accidents is the continuous exercising of good judgment or common sense. All employees should be thoroughly familiar with the safety procedures for their particular jobs. When work is performed on electric equipment, for example, some basic procedures are to (1) de-energize the equipment, (2) use lockout and tagout procedures to ensure that the equipment remains de-energized, (3) use insulating protective equipment, and (4) keep a safe distance from energized parts.

\subsection{ELECTROMAGNETIC INTERFERENCE}

An unwanted electrical signal (noise) generated by EMI can produce undesirable effects in control systems, such as communication errors, undesired state changes, and degraded (or malfunction) equipment performance. Equipment that is susceptible to noise includes computer hardware, electronic circuits, communications links, and sensors that operate in the 0-10 Vdc range. Noise can affect the operation of electric drive system components and produce an undesired or a possible unsafe operating state.

Insulated gate bipolar transistors (IGBTs) are commonly used in electric drive systems for switching. The advantage of IGBTs is their rise- and fall-time switching capability, which is about 10 times faster than that of other devices in the voltage range for the heavy HEV. Thus IGBTs have lower switching losses, are more efficient, and result in smaller drive packages. One significant drawback of using IGBTs is the EMI produced as a result of the rapid changes in voltage (dv/dt) and current (di/dt) with respect to time. The electric drive system will have high-power circuits operating in close proximity to low-power circuits (inverter controller), and noise (undesired electrical signal) can be coupled from the high-power to the low-power circuits and interfere with their operation. EMI is transmitted by conduction and radiation to adjacent components, and the use of grounding and shielding can solve a large 
percentage of EMI problems. A properly designed RC snubber circuit can be effective in reducing the EMIs produced, since it reduces the electrical stresses on a component during switching and limits the rapid change in voltage and current in the circuit. Soft-switching inverters are a design option to eliminate EMI, where the voltage or current is zero at the switching instant. ${ }^{22,24}$ 


\section{FAILURES AND HAZARDS}

The heavy HEV systems being evaluated in this report present some hazards that are not encountered with a conventional heavy vehicle. Loss of containment of the CNG is the most obvious event for the CNG fuel system. Electric shock is the most obvious hazard associated with the electric drive system. The $\mathrm{CNG}$ fuel system contains flammable material, high pressure, and potential energy hazards; and the electric drive system has electrical, kinetic energy, and chemical hazards.

Table 1 contains additional information about design characteristics, requirements, and safety features for heavy HEV equipment. The requirement section explains why the design characteristic is important and the safety type feature section explains how loss of the design characteristic could be detected. The design characteristic matrix is similar to a failure modes and effects anaysis. Table 1 is supplemental safety information for this report.

\subsection{CNG SYSTEM HAZARDS}

The fact that $\mathrm{CNG}$ is stored at high pressure is the most unique physical characteristic of a CNG fuel system. Inadvertent opening of valves or loosening of fittings containing highpressure natural gas can result in not only the creation of a fire hazard, but also the highvelocity ejection of metal parts or fragments that could be lethal to nearby personnel. Training will be key to addressing the hazards of a high-pressure gas, since it is doubtful that a large percentage of the vehicle operations and maintenance personnel will have previously worked with CNG fuel systems.

Ignition of leaking natural gas near the source of a leak will produce a flame similar to that of a gas burner or a torch. Because only a small volume of gas will accumulate, there is reduced danger if the ignition is shortly after the initiation of the leak. Once there is ignition of a CNG leak, the primary subsequent danger is overheating of the CNG container, and the secondary hazard is smoke and fumes from burning vehicle components. A fuel leak should be extinguished by closing a valve between the CNG container and the leak.

Incidents involving ignition of large quantities of accumulated flammable fuel/air mixtures are a possibility, particularly in a building housing heavy HEVs. Large quantities can accumulate from large leaks over a fairly short time period (e.g., from a PRD or main fuel line rupture) or from slow leaks over a long period of time (e.g., from a loose or damaged fitting in the fuel system). Large fuel leaks will produce a large cloud of a flammable mixture that is equal to several gallons of fully vaporized gasoline. The flammable mixture will rise and form a layer under the ceiling in a building without adequate ventilation. Ignition of such a mixture will cause extensive damage as a result of the potential explosion and the subsequent fire. Facilities where CNG vehicles are maintained or stored should be designed with ventilation to prevent accumulation of a flammable mixture, and the location of ignition sources should be controlled to reduce the probability of ignition. ${ }^{2,15}$ 


\subsubsection{CNG Fuel Tank Failure Event}

The failure of a CNG cylinder is the event of most concern for the CNG fuel system. The severity of CNG cylinder failures ranges from an intermittent leak to a fragmented rupture of the cylinder. Essentially all in-service ruptures of CNG cylinders have occurred at or shortly after the completion of filling, when pressure within the cylinders is at a maximum. CNG cylinder failures have also occurred because of exposure to fires. ${ }^{2}$

Failure modes that have been observed for CNG cylinders include intermittent leaks, continuous leaks, fractures, ruptures, and fragmentation ruptures. An intermittent leak occurs when a fatigue crack propagates through the cylinder wall as a result of the stress (i.e., pressure change) associated with repeated filling cycles. When a cylinder with a fatigue crack is at its maximum pressure, the crack is forced open and the cylinder leaks. Intermittent leaks have been observed in all-metal cylinders. Continuous leaks have been seen in Type 4 cylinders as a result of plastic liner defects. The flow rate is typically very low for a continuous leak. A fracture results in a larger opening and a more rapid depressurization than that associated with a continuous leak. In a rupture, the failed cylinder remains in one piece, but damage can result from articles being propelled by the gas escaping at a highvelocity. A fragmented rupture results in the cylinder being fragmented into pieces. ${ }^{2}$

Because there are four basic cylinder designs, any discussion of $\mathrm{CNG}$ container leaks or failures must address the cylinder design type. These four cylinder designs range from the all-metal cylinder (Type 1), the most robust and heaviest design, to the Type 4 cylinder, a composite wrap design with a plastic liner that depends on the composite for durability. The Type 4 cylinder is the lightest design.

Type 1 cylinders are generally safer than composite-based designs, since all-metal cylinders are highly resistant to external damage; but the Type 1 design is the heaviest cylinder design, and weight is an important issue with any vehicle type. The Type 1 design is the most mature design with the most NGV service history. There have been no failures of Type 1 cylinders in the United States in the last 25 years. The Type 1 design is expected to have a 20-year service life. ${ }^{2}$

Type 2 cylinders have a metal liner reinforced with hoop-wrapped continuous filaments in a resin matrix. Hoop-wrapped designs are generally safer than full-wrapped designs because of the redundancy of the liner design (e.g., it can support up to $125 \%$ of the service pressure). The aluminum liner hoop-wrapped design was introduced to NGV service in the United States in 1982, and the steel liner hoop-wrapped design was introduced in 1984. There have been two reported failures of the Type 2 cylinder design in the United States, and both were due to gross degradation of the composite overwrap combined with over-pressurization of the cylinder. There have been many incidences of mechanical damage (detected prior to failure) to the composite wrap as a result of improper installation and environmental attack.

Improvement in the installation code requirements should reduce the incidences of mechanical damage, and coating the glass fibers or the use of fibers resistant to SCC should reduce the incidences of environmental damage. ${ }^{2}$ 
Type 3 cylinders are full-wrapped cylinders consisting of a metal liner that is wrapped with continuous filaments in a resin matrix. The long-term integrity of the composite in a Type 3 cylinder design is more critical to the cylinder's durability and safety than for the Type 2 cylinder design. The Type 3 containers have seen less than 10 years' service in NGVs. The Type 3 cylinder design has advantages compared with Type 4 designs because the metal liner is resistant to leaks and has fewer liner-boss interface concerns. The reinforcement provided by the metal liner likely reduces the flexing and resulting breakage of the composite fiber on impact. There have been four reported failures of Type 3 fiberglass-wrapped cylinders in the United States and many incidences of damage to the composite wrap detected prior to failure. Improvement in the installation code requirements should reduce the incidence of mechanical damage to the composite wrap. The environmental damage issue can be reduced by coating glass fibers with an environmental coating or using fibers that are resistant to SCC. ${ }^{2}$

Type 4 cylinders are full-wrapped cylinders with a gas-tight plastic liner that is non-loadbearing. The composite bears the entire load. The durability of the composite determines the safety and durability of the cylinder. This design is very lightweight and has been used in CNG vehicle applications since 1992. There has been one failure of a Type 4 cylinder, probably due to impact damage. This design is more prone to leaks than the other designs (more than 20 cases of leaking cylinders because there was a cracked liner). Type 4 carbon fiber cylinders are sensitive to impact damage because there is less flexural stiffness of the wall. This allows greater deflection on impact, producing delamination and fiber breakage, which can result in stress rupture. Improvements in process control and inspections are reducing the incidences of plastic liner defects. Operating practices have been revised to avoid the low-pressure/low-temperature fast-fill combination that can wrinkle the plastic liner. $^{2}$

In summary, the Type 4 cylinder is the lightest-weight design, but it is the least mature design and has had problems with plastic liner leaks. The Type 3 cylinder design has more than twice the service history of the Type 4 design and has experienced only three failures. The Type 2 design has been in service for about 18 years, has approximately twice the number of units in service, and has experienced only two failures. The Type 1 design is the safest and the heaviest design. It has the most units in service (by a wide margin), has a demonstrated 20-year life, and has not experienced a failure in the last 25 years in the United States. Probably any of the four cylinder designs will have adequate life times, but the Type 3 and 4 cylinder designs are less durable than the Type 1 and 2 designs. The use of higherpressure CNG cylinders (about 10,000 psi) is being investigated, and this may lead to additional failure modes. ${ }^{2}$

\subsubsection{Pressure Relief Devices}

PRDs are a key component on the CNG fuel system because they open to allow the container to depressurize prior to tank failure or a potential explosion during a fire. These devices should be manufactured by a qualified manufacturer and should be tested every 5 years to demonstrate operability. The PRD should be located so that the PRD and the fuel container are at the same temperature. There can be no valves between the container and the 
PRD, and the outlet line for the PRD must be open. Failure to open and premature opening are two failure modes of concern. If the PRD opens at a pressure lower than its designed pressure, it will most likely reseat itself after a certain pressure drop. Failure to open can result in a tank failure. ${ }^{1,5}$

\subsubsection{Shutoff Valves}

Each CNG container will have a dedicated shutoff valve that can isolate that individual container. There will also be a shutoff valve (downstream from the container shutoff valve) that can isolate all containers. Downstream from the shutoff valve that isolates all containers, there will be an automatic shutoff valve that will automatically close when the ICE shuts down. In summary, there are three shutoff valves between any CNG container and the ICE, and all three must fail before the system will lose the ability to stop the flow of CNG to the engine. If there is a failure of a line, valve, or connector in the CNG fuel system that results in a leak, most likely the leak condition can be isolated. ${ }^{1}$

\subsubsection{Pressure Regulators}

Failure to reduce the pressure would be the most severe failure mode with a pressure regulator. Such a failure could result in higher-pressure natural gas entering the ICE. A pressure regulator could also fail and produce a leak path.

\subsection{ELECTRIC DRIVE SYSTEM HAZARDS}

Electric shock is the event of concern for the electric drive system because of the voltages and currents associated with that system. Battery fires are a concern because of the potential for dissipation of electrochemical energy internally in a faulty battery pack. Short-circuit events are of concern with the inverter because of the high currents and resulting equipment damage that can occur.

The chassis of the heavy HEV will be isolated from the electric drive system and will not be used as the return circuit path as is common with conventional vehicle designs (i.e., 12-V battery voltage level). The vehicle chassis will be used as a floating reference plane for electric drive system components.

The electric drive system must be designed to restrict access to high-voltage components. One way to prevent inadvertent access is the use of access covers with interlock protection. Interlocks should be monitored by a voltage interlock loop circuit that actuates the automatic disconnect if an open circuit is detected. Condition monitoring can reduce the probability of a serious fault because it can detect degradation of equipment in a timely manner. ${ }^{21}$

\subsubsection{Battery Pack Faults}

Battery packs have electrical, chemical, thermal, and potential energy hazards that must be considered in the vehicle design. Electric shock and battery fire are events of concern for the 
battery packs. Restraint of the battery pack and containment of electrolyte are issues that must be addressed in heavy HEV design. ${ }^{10,11}$

Batteries are high-capacity devices with fairly long discharge times under nominal conditions (i.e., low current flow). Battery capacity is the product of current flow and discharge time. Comparing the characteristics of a battery and an electrolytic capacitor will illustrate the differences in their design function. A typical battery has a long discharge time (several minutes), a fairly high energy density (50 to $300 \mathrm{Wh} / \mathrm{L}$ ), and a fairly low cycle-life (200 to 1000 cycles). In contrast, an electrolytic capacitor has a short discharge time (msec), a low energy density $(<0.01 \mathrm{Wh} / \mathrm{L})$ and an infinite cycle life. If a battery is discharged rapidly, it will ultimately fail. ${ }^{8}$

Battery capacity is normally given for a $20^{\circ} \mathrm{C}$ environment and will be reduced at lower temperatures. Batteries are about $80 \%$ efficient in converting chemical energy to electric energy and vice versa. A battery pack will have an efficiency of about $65 \%$ for the complete cycle (i.e., electric to chemical to electric), and the lost energy will appear as heat. The internal resistance of a battery cell determines the losses. The internal resistance will increase with battery temperature and with age (number of cycles). ${ }^{8,9,10}$

Electric shock is a key hazard with battery packs because of the battery voltage levels that are associated with heavy HEVs. More than one fault condition must occur for an occupant of a heavy HEV to receive a serious electric shock. For example, a person could access the $+\mathrm{dc}$ link voltage as a result of a ground fault and not receive an electric shock because the vehicle frame is floating (i.e., not grounded). Two events are required to receive a shock: contact with both the $+\mathrm{dc}$ link and the $-\mathrm{dc}$ link voltage. ${ }^{10,21}$

The battery pack will be electrically isolated from conductive components of the vehicle, and an automatic disconnect will be used to isolate the battery pack from other electric drive system components. Under normal operating conditions, adequate electric isolation is achieved by physical separation, such as the use of insulation, enclosures, and other barriers to direct contact. Loss of electric isolation for the $+\mathrm{dc}$ link voltage would mean there is a current path from the $+\mathrm{dc}$ link to the chassis (i.e., the resistance between the $+\mathrm{dc}$ link voltage and the vehicle frame is less than desired). A general rule is that the electric isolation between the battery voltage and the vehicle conductive structure should be greater than or equal to $500 \mathrm{ohm}$ per volt. This requirement will limit the fault current to $2 \mathrm{~mA} .^{21}$

Loss of electrolyte and failure to restrain are two other safety issues for a heavy HEV battery pack. The battery pack case can fail (leak) as a result of abuse, normal aging, or other reasons and result in loss of electrolyte. The consequence of loss of electrolyte can be minimized by the use of a battery enclosure that has been designed to contain electrolyte. A battery pack will weigh several hundred pounds and must be restrained to control movement. The restraint structure for the battery pack should be designed to limit movement of the battery pack during a vehicle crash. The restraint structure should be substantial and should be secured to the frame of the vehicle. ${ }^{21}$ 
A short-circuit fault can be external or internal to the battery pack. A short-circuit fault that is external to the battery pack can cause the device that is shorting the battery pack to become hot and vaporize, clearing the fault. In high-battery-voltage situations, there is enough energy available to vaporize copper buss bars and other circuitry. If the shorted condition is internal to the battery, a rapid chemical reaction may occur that is dissipated internally in the form of heat. The resulting internal temperature rise literally destroys the defective cell(s) and may vaporize much of the battery. The cells that have not failed dissipate their energy into the failed cells. This type of event, a battery fire, will continue until the battery fails so that it disconnects the circuit or other actions disconnect the fault. ${ }^{9,10,21}$

Battery voltage levels that are outside the desired range for the heavy HEV are of concern. A low battery voltage level will impact the vehicle's ability to operate and can also fail electric drive system components. Battery aging can cause lower output voltage from the battery pack. A higher than desired battery voltage level can result in component failure in the inverter.

Short-circuit conditions, electrolyte leakage, battery gas accumulation, high temperatures, circulating currents, and restraint are safety issues for the battery pack. Short-circuit conditions can occur as a result of contact with a conductive object or conductive electrolyte leakage. A short-circuit event can elevate the battery temperature in a short period of time and produce a meltdown or fire. Electrolyte leakage can produce conductive ground paths and is corrosive. High temperatures can result in loss of electrolyte, and a thermal runaway event can occur. The unintended flow of current can result in discharging or unintended charging that can produce hydrogen or generate overheating.

The battery pack presents electric shock, fire, corrosive, and mechanical (impact) hazards to occupants of the heavy HEV. A properly designed vehicle should be able to adequately limit the hazards presented by the battery packs. $9,10,11$

\subsubsection{Inverter Failure}

Inverters have electric shock and thermal hazards that must be addressed in the design. The inverter will also produce EMI that may affect operation of other electric equipment.

The inverter event of most concern is a short-circuit event that results in excessive current and the subsequent failure of inverter components. A short-circuit condition can be caused by component faults in the controller, power switches, gate controller, low-voltage power supply, or external faults. If, for example, the top and bottom power switches in the same motor phase were "on" at the same time, then a short-circuit would exist that would fail the power switches. Other fault events for the inverter include the generation of excessive noise and thermal problems. ${ }^{12,13}$

Control faults for the inverter could be caused by software, sensor, or microprocessor problems. It is not likely that the software would have a basic control fault because extensive testing of the software that will be required. A more likely software fault would be an unexpected state or error state, data lost as a result of rebooting, or a virus that corrupts the 
software. Sensor faults could result in failure of the controller because of erroneous information. Sensor faults could include sensor failure (loss of output), erroneous sensor output, intermittent sensor faults, and cable or connection faults. Excessive noise spikes (i.e., electromagnetic interference) could compromise the sensor data. Conflicting data from different sensors can result in an inverter failure. ${ }^{22,24}$

A low-voltage power supply (about $5 \mathrm{Vdc}$ ) failure could result in the failure of the inverter because the controller, the gate drive circuit, and sensors require low voltage to operate. If the low-voltage supply's output voltage is higher than required, component failures can result. If the output voltage is lower than specified, then the controller, gate drive circuit, and sensors will not function.

Faults with the gate driver circuit will affect the operation and the state of the power switches. Under-voltage biasing of the power switches can cause overheating and affect the performance of the power switches. Faults that result in longer-than-expected switch turnoff times could result in a power switch being in the "on" state when it should be in the "off" state. Thermal faults with the power switches could be due to improper mounting of switches to the heat sink, heat compound problems, or cooling system faults. $^{12,13}$

An inverter can produce imbalanced phase voltages because of mismatched power switches or bad (high-resistance) connections that can affect the life of the motor. A voltage imbalance of $5 \%$ can result in a current imbalance of $20 \%$ or greater. A noticeable current imbalance can result in higher winding temperatures with the phases that have larger currents. ${ }^{13}$

Fault-tolerant inverters are being developed for specific vehicle applications. These inverters can detect fault conditions and inhibit operation of the inverter, but more components and higher inverter costs are required.

The current flow in an inverter is bi-directional because the electric drive motor can act as a generator as the motor decelerates and direct current through the inverter to the battery pack. If this flow of current is interrupted, then components in the inverter can fail. The filter capacitors in the inverter will remain charged for a period of time (less than 5 minutes after the key switch is turned off), and this presents a shock hazard until they discharge.

\subsubsection{Motor Failure}

The drive motor has electric shock and mechanical and potential energy hazards that must be considered. Rotating components in the electric motor can fail and produce a projectile. A proper mechanical design with adequate safety margins should address these hazards.

The electric drive system may use a permanent magnet motor, induction motor, or switched reluctance motor. Since each type of motor has different designs, any discussion of motor failures must address the type of motor being used. General motor faults include stator, rotor, bearing, connector, and cooling faults. ${ }^{13}$ 
A motor is designed for a maximum temperature consistent with the insulating materials, bearings, and lubrication. Four temperature classes, A, B, F, and $\mathrm{H}$, are recognized for motors. Operating a motor above the maximum rated temperature (i.e., $180^{\circ} \mathrm{C}$ for a Class $\mathrm{H}$ ) will result in a shorter life as a result of the insulation's losing its mechanical and electrical strength. Thus the motor must be designed to ensure that the insulation does not operate above the maximum temperature capability of the insulation. The limiting temperature is based on an average winding temperature as measured by change in resistance. The average winding temperature in a Class A motor may reach $140^{\circ} \mathrm{C}$ when the thermal protector trips, and it might reach $215^{\circ} \mathrm{C}$ in a Class $\mathrm{H}$ motor. If the motor does not have thermal protection and the motor is misapplied, the windings will reach a higher temperature before the motor fails. ${ }^{25}$

A stator will contain insulated windings in a grounded laminated steel stack. In a stator, there are many conductors that must be insulated from each other and the ground. The insulation system is selected based on its dielectric properties, but it is also stressed mechanically by thermal expansion, vibration, and shock. Dirt, contamination, vehicle fluid, and moisture produce chemical stresses. The first few dielectric failures in the insulation system of a particular motor design will usually be due to damage during manufacturing or excessive thermal aging. Most failures start with mechanical cracking that results in shorts and ground faults. The motor insulation system must be designed to handle transient voltage of $1.5 \mathrm{kV}$ or more, since the inverter will be utilizing PWM. ${ }^{12,13,25}$

Stator faults include imbalanced phase currents, phase-to-phase short-circuit conditions, phase-to-core short-circuit conditions, and connector problems. Operation of a motor with voltage imbalances of approximately $5 \%$ will result in current imbalances that can be greater than $20 \%$. Current imbalances of this magnitude will result in a noticeably higher winding temperature that will shorten the motor's life. Phase imbalances could result from inverter problems or winding defects caused by poor workmanship. Inverter faults can result in application of higher voltages or currents that reduce the efficiency of the motor and produce higher winding temperatures. ${ }^{25}$

For a permanent magnet motor, magnet faults and position sensor faults must be considered. A magnet can become a projectile if the magnet retainer fails in the rotor. The magnets can be damaged if an elevated temperature causes the magnets to lose their magnetic strength. The permanent magnet motor and SRM requires absolute indication of the position of the rotor, and faults in the position sensor can result in failure of the motor. ${ }^{25}$

Bearing failures are a major problem caused by mechanical damage, vibration, and inadequate lubrication. Foreign material in the lubricant may scratch the contact surface and remove tiny chips of bearing material, severely shortening the life of the bearing. Electric current passing through the bearing (because of a ground fault) will cause arcing, local melting, and progressive damage to the rolling contact surfaces. ${ }^{25}$ 


\subsubsection{Cable Failure}

The insulation on a cable could break down, resulting in loss of isolation between the conductor and the vehicle's frame. This could subject a person performing maintenance on the vehicle to a shock hazard if it was not determined that a fault event existed. The cables present electric shock hazard, but routing the cables outside the passenger compartment and having adequate insulation should address this hazard.

\subsection{INTERACTION HAZARDS}

The electric drive system and CNG fuel systems hazards have been addressed separately, but interactions between these two systems must be considered. The electric drive system provides ignition sources and hot surfaces with the potential thermal energy to ignite any natural gas that leaks from the CNG fuel system. A fire could originate in one system, and spread to, damage, or be fueled by the other system. For example, a battery fire could spread to the CNG fuel containers, or a CNG fuel system fire could spread to the battery compartment. Physical barriers and separation between these two systems should limit unwanted interactions, but there is potential for interactions given a severe crash event. A more detailed evaluation of interactions should be performed prior to the final design.

\subsection{MAINTENANCE HAZARDS}

The heavy HEV design provides new hazards to the maintenance facility and personnel. The electric drive system presents electric shock hazards to the maintenance personnel that may require additional training and planning for maintenance of the electric drive system. Awareness of the potential consequence of accidents should be reviewed in great detail. Scenarios should be developed and reviewed for accidents, such as dropping a conductive tool onto the battery pack or failing to secure the manual disconnect prior to performing maintenance on the electric drive system. The CNG fuel system has hazards associated with the high pressure of the natural gas. Handling or removing a cylinder from a vehicle should be done only when absolutely necessary and should be done with great caution. The use of atmospheric venting of natural gas to depressurize a natural gas cylinder must be done with care. Improper equipment or procedures raise the risk of fire from gas being ignited by nearby flames, ignition sources, or static discharge. A static electrical charge can build up during venting of gas and can ignite the natural gas.

Since natural gas is lighter than air, it will rise if there is a leak, and a flammable mixture can form in the maintenance facility. The maintenance facility should be designed to prevent or control how long a flammable layer of natural gas can exist near the ceiling. The ventilation system should be designed to remove air from above the vehicle or promote the mixing of the air in spaces above the vehicles. Ignition sources above the heavy HEV are of primary concern. Ignition sources include electric equipment that generates sparks or has high surface temperatures, and open-flame heaters. A natural gas detection system should be installed in the maintenance facility with audible and visible alarm indicators when a maximum of onefifth of the lower flammable limit is reached. 


\subsection{CRASH HAZARDS}

A heavy HEV will have additional weight because of the battery packs and the CNG containers; this additional weight must not affect the crashworthiness or stability of the vehicle. The vehicle must be designed to restrain the movement of the battery packs and fuel containers during a crash. The fuel containers should be located where they can survive a crash and contain the natural gas. Each fuel supply container should be mounted in a location that will minimize damage from a collision. No portion of a fuel supply container or container appurtenance should be located ahead of the front axle or behind the vehicle's frame. Container valves should be protected from physical damage by the vehicle structure, valve protector, or a suitable metal shield. The vehicle should have an inertia switch that is an input to the automatic disconnect so that the battery voltage is isolated from the electric drive system following a crash. Some form of crash testing should be considered. 


\section{REFERENCES}

1. Compressed Natural Gas (CNG) Vehicle Fuel System Code, NFPA 52, National Fire Protection Association, Inc., July 1985.

2. Compressed Natural Gas Storage Optimization for Natural Gas Vehicles, GRI96/0364, Gas Research Institute, December 1996.

3. R. Wilcox, et al., "Risk-Based Technology Methodology for the Safety Assessment of Marine Compressed Natural Gas Fuel System, ”International Cooperation on Marine Engineering Systems/The Society of Naval Architects and Marine Engineers, May 22-23, 2000.

4. D. Stephens, Industrial Needs for Development of Smart Onboard Inspection of HighPressure Gas Fuel Cylinders, Battelle Energy Systems Division, March 1998.

5. T. Kletz, What Went Wrong-Case Histories of Process Plant Disasters, Butterworth-Heinemann, 1999.

6. "Recommended Environmental Practices for Electronic Equipment Design," SAE J1211, SAE International, Society of Automotive Engineers, Warrendale, PA, June 1978.

7. F. Kalhammer, EV and HEV Batteries: Requirements and Prospects, Advanced Battery Readiness Ad Hoc Working Group, Washington, D.C., February 28, 2001.

8. A. Burke, "Batteries and Ultracapacitors Alone and In Combination For Vehicle Applications," SAE Toptec, HEVs in the Market, June 26-27, 2002. Ft. Myers Beach, Florida.

9. R. L. Taylor, Lead-Acid Battery Hazards, Calicorp, Inc., Technical Notes, 1999.

10. D. Rand, et al., "Batteries for Electric Vehicles," SAE International, Society of Automotive Engineers, Warrendale, PA, 1998.

11. Results of Electric Vehicle Safety Issues Survey, Conducted on behalf of Ad Hoc EV Battery Readiness Working Group In-Vehicle Safety Sub-Working Group, DOE/ID10542, June 1996.

12. N. Mohan, et al., Power Electronics-Converters, Applications, and Design, John Wiley and Sons, Inc., 1995.

13. P. C. Sen, Principles of Electric Machines and Power Electronics, John Wiley and Sons, Inc., 1997 
14. C. W. Ayers, Electrical Signature Analysis for Automotive Alternator Diagnostics, Sound and Vibration Magazine, 32(2), 1998.

15. R. L. Bechtold, Alternative Fuels Guidebook, Properties, Storage, Dispensing, and Vehicle Facility Modifications, Society of Automotive Engineers, Inc, 1997.

16. Gas Engineers Handbook, Industrial Press, Inc., 1965.

17. D. S. Smith, "Static Electricity in PE Fuel Gas Pipe," Pipeline and Gas Journal, December 2001.

18. H. Montiel, et al., 1996, "Historical Analysis of Accidents in the Transportation of Natural Gas,” Journal of Hazardous Materials, May 1996.

19. L. Van Vlack, Elements of Material Science, Addison-Wesley Publishing Company, 1964.

20. E. Magison, "Electrical Instruments in Hazardous Locations," Instrument Society of America, 1998.

21. "Guidelines for Electric Vehicle Safety," SAE J2344, SAE International, Society of Automotive Engineers, Warrendale, PA, June 1998.

22. H. W. Ott, Noise Reduction Techniques in Electronic Systems, John Wiley and Sons, Inc., 1976.

23. P. Lefferson, DC Leakage Current Detector Protects the High Voltage Equipment User, PCIM, September 2000.

24. G. Skibinski, et al., "Generation, Control, and Regulation of EMI for AC Drives," IEEE Industrial Application Society, Annual Meeting, New Orleans, Louisiana, October 5-9, 1997.

25. R. Engelmann, et al., Handbook of Electric Motors, Marcel Dekker, Inc., 1995. 
7. TABLE 1. DESIGN CHARACTERISTIC MATRIX.

\begin{tabular}{|c|c|c|c|}
\hline $\begin{array}{l}\text { Component/ } \\
\text { equipment }\end{array}$ & Design characteristic & Requirement & Safety type feature \\
\hline \multicolumn{4}{|l|}{$\begin{array}{l}\text { Electric drive } \\
\text { system }\end{array}$} \\
\hline \multirow[t]{6}{*}{ Battery packs } & $\begin{array}{l}\text { Battery packs with } \\
\text { significant voltage } \\
\text { differences should not be } \\
\text { adjacent to each other }\end{array}$ & $\begin{array}{l}\text { Components with high voltage differences should be } \\
\text { separated to prevent potential short-circuit conditions and } \\
\text { to reduce the magnitude of leakage currents }\end{array}$ & $\begin{array}{l}\text { Position battery packs to } \\
\text { minimize the voltage difference } \\
\text { between adjacent battery packs }\end{array}$ \\
\hline & $\begin{array}{l}\text { Prevent the accumulation } \\
\text { of moisture or dirt on } \\
\text { battery surface }\end{array}$ & $\begin{array}{l}\text { Surfaces of battery packs should be periodic ally cleaned } \\
\text { to prevent the accumulation of moisture or dirt to reduce } \\
\text { the chance of leakage current paths }\end{array}$ & $\begin{array}{l}\text { Prevent accumulation of } \\
\text { moisture or dirt on battery } \\
\text { packs }\end{array}$ \\
\hline & $\begin{array}{l}\text { Battery packs have } \\
\text { reduced discharge and } \\
\text { charge capability when } \\
\text { they are operated outside } \\
\text { their temperature range } \\
\text { for efficient operation }\end{array}$ & $\begin{array}{l}\text { When a vehicle is initially activated, during extreme } \\
\text { temperature conditions, operation (discharging or } \\
\text { charging) of the battery bank may be minimized or } \\
\text { inhibited until the battery packs reach the allowed } \\
\text { temperature range to be charged or discharged. At cold } \\
\text { temperatures, the battery packs (depending on the type of } \\
\text { battery packs used) may accept only a low rate of charge }\end{array}$ & $\begin{array}{l}\text { Monitor the battery pack } \\
\text { temperature prior to charging or } \\
\text { discharging the battery packs. } \\
\text { The internal combustion engine } \\
\text { heat can be used to warm } \\
\text { and/or the air conditioner can } \\
\text { be used to cool the } \\
\text { battery/battery compartment }\end{array}$ \\
\hline & $\begin{array}{l}\text { Ventilation of the battery } \\
\text { compartment }\end{array}$ & $\begin{array}{l}\text { A ventilation fan may be required to prevent the buildup } \\
\text { of hydrogen during recharging or to control the } \\
\text { temperature of the battery compartment. A sensor may be } \\
\text { required to detect the buildup of hydrogen or to detect a } \\
\text { temperature increase in the compartment }\end{array}$ & $\begin{array}{l}\text { Hydrogen sensors and } \\
\text { ventilation fan }\end{array}$ \\
\hline & $\begin{array}{l}\text { Ventilation of the battery } \\
\text { compartment }\end{array}$ & $\begin{array}{l}\text { The source of the air and the location of the discharge } \\
\text { should be checked for assurance that the air is not or } \\
\text { cannot be discharged into the passenger compartment }\end{array}$ & $\begin{array}{l}\text { Discharge battery compartment } \\
\text { air outside the vehicle }\end{array}$ \\
\hline & $\begin{array}{l}\text { Monitoring the state of } \\
\text { charge of the battery bank }\end{array}$ & $\begin{array}{l}\text { The state of charge of the battery bank should be } \\
\text { monitored to prevent overcharging of the battery packs. } \\
\text { Repeated overcharging can lead to deterioration in } \\
\text { battery performance }\end{array}$ & $\begin{array}{l}\text { Use correct monitoring } \\
\text { technique to monitor the state } \\
\text { of charge of the battery packs }\end{array}$ \\
\hline
\end{tabular}




\begin{tabular}{|c|c|c|c|}
\hline & $\begin{array}{l}\text { Recommended charging } \\
\text { technique should be used }\end{array}$ & $\begin{array}{l}\text { The correct charging technique should be used based on } \\
\text { the type battery packs (e.g., lead acid) that are utilized in } \\
\text { the vehicle }\end{array}$ & $\begin{array}{l}\text { Verify correct charging } \\
\text { technique based on the type } \\
\text { battery packs (e.g., lead acid) }\end{array}$ \\
\hline & $\begin{array}{l}\text { Monitor internal } \\
\text { resistance of the battery } \\
\text { packs }\end{array}$ & $\begin{array}{l}\text { At the battery package, there will be an increase in } \\
\text { internal resistance due to corrosion and other aging } \\
\text { effects. The increased resistance will reduce the available } \\
\text { current to the power electronics and reduce the capability } \\
\text { of the vehicle }\end{array}$ & $\begin{array}{l}\text { Monitor the internal resistance } \\
\text { of the battery packs to } \\
\text { determine when to replace the } \\
\text { battery packs }\end{array}$ \\
\hline & Battery restraint & $\begin{array}{l}\text { During a vehicle crash, battery packs could become } \\
\text { projectiles and injury passengers or cause additional } \\
\text { damage to the vehicle or to other vehicles }\end{array}$ & $\begin{array}{l}\text { Secure the battery/battery } \\
\text { compartment to the frame to } \\
\text { prevent the free movement of } \\
\text { the battery packs }\end{array}$ \\
\hline & Battery restraint & $\begin{array}{l}\text { Failure to restrain battery movement could result in high } \\
\text { leakage current, a short-circuit condition, and battery fire }\end{array}$ & $\begin{array}{l}\text { Ensure that dc link and battery } \\
\text { packs have a fusible link }\end{array}$ \\
\hline & Battery restraint & $\begin{array}{l}\text { If there is sufficient movement of the battery packs so } \\
\text { that a battery terminal or interconnection comes into } \\
\text { contact with a metal object, then a short-circuit condition } \\
\text { and fire could occur }\end{array}$ & $\begin{array}{l}\text { Construct battery container of } \\
\text { non-conductive material }\end{array}$ \\
\hline & $\begin{array}{l}\text { Containment of fluids in } \\
\text { the battery compartment }\end{array}$ & $\begin{array}{l}\text { The battery packs must be contained in a lined container } \\
\text { that will limit the amount of battery fluid that can be } \\
\text { spilled. The container must be constructed of material } \\
\text { that will not be corroded by battery acid }\end{array}$ & $\begin{array}{l}\text { Contain the battery in a } \\
\text { compartment designed to } \\
\text { contain any spilled battery fluid } \\
\text { and construction material } \\
\text { compatible with battery } \\
\text { electrolyte }\end{array}$ \\
\hline & $\begin{array}{l}\text { Interconnect between } \\
\text { battery packs }\end{array}$ & $\begin{array}{l}\text { Any battery interconnections should be torqued to } \\
\text { appropriate values. A flexible interconnection may be } \\
\text { preferable to a solid interconnect }\end{array}$ & $\begin{array}{l}\text { Use a flexible interconnection } \\
\text { that does not transfer vibrations } \\
\text { and provides better protection } \\
\text { for a short-circuit condition } \\
\text { than a solid buss bar }\end{array}$ \\
\hline $\begin{array}{l}\text { Contactors } \\
\text { (automatic } \\
\text { disconnectors) }\end{array}$ & $\begin{array}{l}\text { The contactors should be } \\
\text { located near the battery } \\
\text { packs }\end{array}$ & $\begin{array}{l}\text { The contactors should be located near the battery } \\
\text { compartment to minimize the length of cable, between } \\
\text { the battery packs and contactors, that remains energized } \\
\text { when the contactors are open }\end{array}$ & Locate contactors properly \\
\hline
\end{tabular}




\begin{tabular}{|c|c|c|c|}
\hline & $\begin{array}{l}\text { There should be sufficient } \\
\text { separation between the } \\
\text { two contactors }\end{array}$ & $\begin{array}{l}\text { There should be sufficient separation between the }+ \text { and }- \\
\text { dc link contactors that there is no potential for a short- } \\
\text { circuit condition to occur between the two contactors }\end{array}$ & $\begin{array}{l}\text { Provide adequate spacing } \\
\text { between contactors }\end{array}$ \\
\hline & $\begin{array}{l}\text { Key switch is an input to } \\
\text { the control circuit for the } \\
\text { contactors }\end{array}$ & $\begin{array}{l}\text { When the key switch is placed in the "off" position, the } \\
\text { control circuit should open the contactors. Capacitors in } \\
\text { the power electronics will discharge the battery packs if } \\
\text { the contactors fail to open while the vehicle is inactive. } \\
\text { When the key switch is placed in the "on" position, the } \\
\text { contactors will close after a short delay to charge the } \\
\text { precharge capacitors (inverter). This precharge time } \\
\text { reduces the electrical stress on the power electronic } \\
\text { components by limiting the change in voltage with } \\
\text { respect to time }\end{array}$ & $\begin{array}{l}\text { Ensure that a contactor on the }+ \\
\text { and - dc link opens to isolate } \\
\text { the battery packs from the } \\
\text { power electronics. The } \\
\text { contactors must close after the } \\
\text { precharge capacitors are } \\
\text { charged }\end{array}$ \\
\hline & $\begin{array}{l}\text { The contactors must open } \\
\text { when the vehicle is in an } \\
\text { impact accident }\end{array}$ & $\begin{array}{l}\text { The vehicle's electrical system must be isolated from the } \\
\text { dc power source if there is an accident to prevent } \\
\text { emergency response personnel, tow truck operator, or } \\
\text { others from potentially accessing the high voltage }\end{array}$ & $\begin{array}{l}\text { Provide an inertia switch that is } \\
\text { an input to the control circuit } \\
\text { for the contactors }\end{array}$ \\
\hline $\begin{array}{l}\text { Manual } \\
\text { disconnect }\end{array}$ & $\begin{array}{l}\text { Backup means of } \\
\text { isolation the dc power } \\
\text { source from the electrical } \\
\text { system }\end{array}$ & $\begin{array}{l}\text { The vehicle should have a manual disconnect that can be } \\
\text { used to isolate the dc power source. The manual } \\
\text { disconnect will be a backup to the contactors and provide } \\
\text { assurance that the electrical system is isolated }\end{array}$ & $\begin{array}{l}\text { Make the manual disconnect } \\
\text { easy to access, well marked, } \\
\text { and in a standard location }\end{array}$ \\
\hline \multirow[t]{2}{*}{$\begin{array}{l}\text { dc cables } \\
\text { (contactors to } \\
\text { inverter) }\end{array}$} & $\begin{array}{l}\text { Color of the insulation of } \\
\text { the dc cable should } \\
\text { designate high voltage }\end{array}$ & $\begin{array}{l}\text { The dc cables between the contactors and inverter must } \\
\text { be color-coded to indicate high voltage. This designation } \\
\text { is very important for emergency response personnel, tow } \\
\text { truck operators, and the general public that may respond } \\
\text { to an accident. There needs to be some level of training } \\
\text { for the general public about this color-coding }\end{array}$ & $\begin{array}{l}\text { Use color-coded insulation on } \\
\text { all wiring that will be operating } \\
\text { with a voltage level of } 50 \mathrm{~V} \text { or } \\
\text { higher }\end{array}$ \\
\hline & $\begin{array}{l}\text { The dc cables should be } \\
\text { routed under the } \\
\text { passenger compartment } \\
\text { in a manner to minimize } \\
\text { the possibility of a shock } \\
\text { hazard }\end{array}$ & $\begin{array}{l}\text { The routing path of the dc cables should be outside the } \\
\text { passenger compartment, and they should be routed in a } \\
\text { manner that reduces the chance of mechanical damage to } \\
\text { the cable }\end{array}$ & $\begin{array}{l}\text { Locate dc cables outside the } \\
\text { passenger compartment }\end{array}$ \\
\hline
\end{tabular}




\begin{tabular}{|c|c|c|c|}
\hline & $\begin{array}{l}\text { Protective devices or } \\
\text { grommets should be used } \\
\text { where there is a } \\
\text { penetration }\end{array}$ & $\begin{array}{l}\text { Where the cable penetrates firewall or other metal } \\
\text { surfaces, grommets or other protective devices should be } \\
\text { used }\end{array}$ & $\begin{array}{l}\text { Use grommets or other } \\
\text { protective device }\end{array}$ \\
\hline & Wire size of cables & $\begin{array}{l}\text { The wire size should be adequate for the intended current } \\
\text { flow }\end{array}$ & Use wire of the proper size \\
\hline & Insulation & $\begin{array}{l}\text { Wire designated, as automotive grade should be used. } \\
\text { The use of improper wire that is not designed for } \\
\text { automotive fluids can result in cracked or damaged } \\
\text { insulation that can contribute to ground faults }\end{array}$ & $\begin{array}{l}\text { Use insulation designed for } \\
\text { vehicle applications }\end{array}$ \\
\hline & $\begin{array}{l}\text { Monitor the dc current } \\
\text { and isolate the electric } \\
\text { drive system from the } \\
\text { battery voltage if the } \\
\text { maximum current level is } \\
\text { exceeded }\end{array}$ & $\begin{array}{l}\text { There should be a maximum current that is expected to } \\
\text { occur during normal operation, and the dc cables should } \\
\text { be isolated from the dc power supply if this value is } \\
\text { exceeded. This would indicate a fault condition }\end{array}$ & Use current sensors \\
\hline & $\begin{array}{l}\text { Monitor and isolate the } \\
\mathrm{dc} \text { power supply if there } \\
\text { is a difference between } \\
\text { the - dc cable and }+\mathrm{dc} \\
\text { cable current }\end{array}$ & $\begin{array}{l}\text { If there is a difference between the two currents, then } \\
\text { there is a fault condition and the contactors should be } \\
\text { opened }\end{array}$ & Use current sensors \\
\hline & $\begin{array}{l}\text { The cable should be of } \\
\text { minimum length and the } \\
\text { cables should be } \\
\text { interwoven }\end{array}$ & $\begin{array}{l}\text { The length of the cables should be as short as possible } \\
\text { and the cables should be interwoven (twisted) to } \\
\text { minimize the inductance }\end{array}$ & $\begin{array}{l}\text { Use a proper cable length and } \\
\text { twist cables }\end{array}$ \\
\hline \multirow[t]{3}{*}{ Inverter } & $\begin{array}{l}\text { Pre-charge capability of } \\
\text { inverter }\end{array}$ & $\begin{array}{l}\text { Pre-charge limits the initial voltage spike when the power } \\
\text { electronics are activated (i.e., contactors close to apply } \\
\text { battery voltage to inverter). Then the inverter is charged } \\
\text { to } 100 \text { percent of the dc battery voltage }\end{array}$ & Provide pre-charge capability \\
\hline & Power connectors & $\begin{array}{l}\text { Power connectors must be capable of conducting the } \\
\text { current and provide shielding to prevent electromagnetic } \\
\text { interference }\end{array}$ & $\begin{array}{l}\text { Use proper power connector } \\
\text { design }\end{array}$ \\
\hline & Insulated gate bipolar & Devices switch "on" and "off" at high frequency to & Provide IGBT and diode \\
\hline
\end{tabular}




\begin{tabular}{|c|c|c|c|}
\hline & $\begin{array}{l}\text { transistor (IGBT) and } \\
\text { diode inverter module } \\
\text { current and voltage rating }\end{array}$ & $\begin{array}{l}\text { convert the dc input voltage to pulse width modulated } \\
\text { output }\end{array}$ & specification \\
\hline & $\begin{array}{l}\text { Current and voltage } \\
\text { rating }\end{array}$ & $\begin{array}{l}\text { The current and voltage rating of the switching devices } \\
\text { meet the requirements of the inverter }\end{array}$ & $\begin{array}{l}\text { Provide IGBT and diode } \\
\text { specification }\end{array}$ \\
\hline & $\begin{array}{l}\text { Diode rating (reverse } \\
\text { current) }\end{array}$ & $\begin{array}{l}\text { The current rating of the diodes should be compared to } \\
\text { the rating of the power switches }\end{array}$ & $\begin{array}{l}\text { Provide diodes with adequate } \\
\text { proper current rating }\end{array}$ \\
\hline & $\begin{array}{l}\text { Thermal shutdown } \\
\text { protection }\end{array}$ & $\begin{array}{l}\text { The inverter should provide thermal protection of the } \\
\text { power switches that will shut down the inverter if } \\
\text { required }\end{array}$ & $\begin{array}{l}\text { Provide thermal shutdown } \\
\text { protection }\end{array}$ \\
\hline & $\begin{array}{l}\text { Thermal performance of } \\
\text { heat exchanger }\end{array}$ & $\begin{array}{l}\text { The heat exchanger dissipates the heat gathered from the } \\
\text { power semiconductors and the ripple capacitors to the } \\
\text { coolant }\end{array}$ & $\begin{array}{l}\text { Provide adequate heat transfer } \\
\text { characteristics }\end{array}$ \\
\hline & Power connectors & $\begin{array}{l}\text { Power connectors should be sized for the currents and } \\
\text { voltage associated with the electric drive system }\end{array}$ & $\begin{array}{l}\text { Size connector for current and } \\
\text { voltage rating }\end{array}$ \\
\hline & Bus structure & $\begin{array}{l}\text { Verify current and voltage handling capacity of the dc } \\
\text { bus structure }\end{array}$ & $\begin{array}{l}\text { Verify current and voltage } \\
\text { rating }\end{array}$ \\
\hline & Ripple capacitors & $\begin{array}{l}\text { Ripple capacitors are attached to the bus structure and } \\
\text { carry the high frequency PWM currents. The ripple } \\
\text { capacitors serve as a snubber to limit turn-off voltage } \\
\text { spikes across the IGBT switches }\end{array}$ & $\begin{array}{l}\text { Provide proper ripple capacitor } \\
\text { specification }\end{array}$ \\
\hline & Inverter restraint & $\begin{array}{l}\text { Inverter should be restrained from movement by being } \\
\text { secured to the frame of the vehicle }\end{array}$ & Verify restraint connection \\
\hline & $\begin{array}{l}\text { Inverter case should be } \\
\text { grounded to vehicle } \\
\text { frame }\end{array}$ & $\begin{array}{l}\text { Vehicle frame should serve as a ground plane for the } \\
\text { vehicle }\end{array}$ & Ground equipment \\
\hline \multirow[t]{3}{*}{ Electric motor } & $\begin{array}{l}\text { Continuous rating of } \\
\text { traction motor }\end{array}$ & $\begin{array}{l}\text { The electric motor should have a continuous rating that is } \\
\text { adequate for the size of the vehicle }\end{array}$ & $\begin{array}{l}\text { Ensure continuous rating for } \\
\text { electric motor }\end{array}$ \\
\hline & $\begin{array}{l}\text { Peak rating of traction } \\
\text { motor }\end{array}$ & $\begin{array}{l}\text { The electric motor should have a peak rating that is } \\
\text { adequate for the size of the vehicle. The motor should be } \\
\text { capable of operating at this rating level for a couple of } \\
\text { minutes (e.g., during acceleration) }\end{array}$ & $\begin{array}{l}\text { Ensure peak rating of electric } \\
\text { motor }\end{array}$ \\
\hline & Stator temperature should & Verify that the stator temperature is monitored and if a & Provide stator temperature \\
\hline
\end{tabular}




\begin{tabular}{|c|c|c|c|}
\hline & be monitored & $\begin{array}{l}\text { higher than desired temperature is detected, then } \\
\text { operation of electric motor should be inhibited }\end{array}$ & monitor \\
\hline & $\begin{array}{l}\text { Phase currents are } \\
\text { monitored }\end{array}$ & $\begin{array}{l}\text { The motor phase currents should be monitored and action } \\
\text { taken if a significant difference in the phase current is } \\
\text { detected }\end{array}$ & Provide current monitoring \\
\hline & Restraint of motor & $\begin{array}{l}\text { Motor should be restrained from movement by being } \\
\text { attached to vehicle frame by adequately sized bolts. }\end{array}$ & $\begin{array}{l}\text { Ensure that bolts are of an } \\
\text { adequate size }\end{array}$ \\
\hline & $\begin{array}{l}\text { Insulation rating of the } \\
\text { motor }\end{array}$ & $\begin{array}{l}\text { The insulation rating for the motor will determine the } \\
\text { average winding temperature that the motor can operate }\end{array}$ & $\begin{array}{l}\text { Determine insulation rating of } \\
\text { the motor }\end{array}$ \\
\hline \multirow[t]{5}{*}{$\begin{array}{l}\text { CNG fuel } \\
\text { container }\end{array}$} & $\begin{array}{l}\text { The CNG fuel tanks must } \\
\text { be capable of containing } \\
\text { the CNG at service } \\
\text { pressure without } \\
\text { experiencing a leak }\end{array}$ & $\begin{array}{l}\text { The fuel tank must be designed to withstand the pressures } \\
\text { exerted by the gas on the walls of the container for the } \\
\text { service life of the containers }\end{array}$ & $\begin{array}{l}\text { Use container designed for the } \\
\text { service application. }\end{array}$ \\
\hline & Ability to survive a crash & $\begin{array}{l}\text { The fuel tanks must be capable of surviving the forces } \\
\text { exerted on it during a vehicle crash }\end{array}$ & $\begin{array}{l}\text { Use container designed for the } \\
\text { service application }\end{array}$ \\
\hline & $\begin{array}{l}\text { Location to minimize } \\
\text { damage }\end{array}$ & $\begin{array}{l}\text { No portion of the fuel supply container or container } \\
\text { accessory should be located ahead of the front axle or } \\
\text { behind the point of attachment of the rear bumper to the } \\
\text { vehicle. No portion of the fuel supply container or } \\
\text { container accessory should protrude beyond the sides or } \\
\text { top of the vehicle at the point where it is installed }\end{array}$ & $\begin{array}{l}\text { Ensure proper location of } \\
\text { container }\end{array}$ \\
\hline & $\begin{array}{l}\text { Location of fuel } \\
\text { containers }\end{array}$ & $\begin{array}{l}\text { Fuel supply containers on vehicles should be permitted to } \\
\text { be located within, below, or above the driver or } \\
\text { passenger compartment, provided all connections to the } \\
\text { container are external to, or sealed and vented from, these } \\
\text { compartments }\end{array}$ & $\begin{array}{l}\text { Follow requirements for } \\
\text { connections to fuel containers }\end{array}$ \\
\hline & $\begin{array}{l}\text { Protection of road } \\
\text { hazards }\end{array}$ & $\begin{array}{l}\text { Containers should be protected to prevent damage due to } \\
\text { road hazards, loading, unloading, and protected from } \\
\text { exhaust heat. The fuel system should be installed with as } \\
\text { much road clearance as practical, but with not less than } \\
\text { the minimum road clearance of the vehicle when loaded } \\
\text { to its gross vehicle weight rating }\end{array}$ & $\begin{array}{l}\text { Requirements to address road } \\
\text { clearance and exhaust heat }\end{array}$ \\
\hline
\end{tabular}




\begin{tabular}{|c|c|c|c|}
\hline & $\begin{array}{l}\text { Tank constructed of } \\
\text { allowable materials }\end{array}$ & $\begin{array}{l}\text { Allowable materials are limited to } 4130 \mathrm{X} \text { steel or } \\
\text { equivalent, aluminum alloys (AA6010 or AA6061) and } \\
\text { certain composites (E-glass, S-glass, aramid, or carbon } \\
\text { fibers in an epoxy, polyester, vinyl ester, or thermoplastic } \\
\text { resin) }\end{array}$ & $\begin{array}{l}\text { Use allowable materials of } \\
\text { construction for fuel containers }\end{array}$ \\
\hline & $\begin{array}{l}\text { Pressure relief device } \\
\text { (PRD) for each container }\end{array}$ & $\begin{array}{l}\text { Each container should have a PRD that vents to the } \\
\text { outside of the vehicle. The PRD will be located so that it } \\
\text { is at the same temperature as the fuel container and there } \\
\text { will be no obstruction between PRD and container }\end{array}$ & $\begin{array}{l}\text { Provide a PRD for each } \\
\text { container }\end{array}$ \\
\hline & Shutoff valve & $\begin{array}{l}\text { Each container should have a dedicated shutoff valve so } \\
\text { that each container can be isolated from the fuel system }\end{array}$ & $\begin{array}{l}\text { Provide a container shutoff } \\
\text { valve for each container }\end{array}$ \\
\hline & Container support & $\begin{array}{l}\text { The container weight should not be supported by a fuel } \\
\text { system component. Metal clamping bands and their } \\
\text { supports should not be in direct contact with a container. } \\
\text { A mounting system should minimize fretting corrosion } \\
\text { between the container and the mounting system }\end{array}$ & $\begin{array}{l}\text { Follow container support } \\
\text { requirements }\end{array}$ \\
\hline & All metal containers & $\begin{array}{l}\text { A recognized quality system will be used and every } \\
\text { cylinder will have the following production inspection } \\
\text { tests: hardness testing, ultrasonic scanning, and } \\
\text { hydrostatic proof testing }\end{array}$ & $\begin{array}{l}\text { Follow requirements for all } \\
\text { metal containers }\end{array}$ \\
\hline $\begin{array}{l}\text { Gas tight } \\
\text { enclosure }\end{array}$ & $\begin{array}{l}\text { Requirement if leak can } \\
\text { enter passenger } \\
\text { compartment }\end{array}$ & $\begin{array}{l}\text { The neck of the tank and all CNG fittings within the } \\
\text { compartment should be enclosed in a gastight enclosure } \\
\text { that is vented directly to the outside of the vehicle }\end{array}$ & Follow enclosure requirements \\
\hline \multirow[t]{2}{*}{$\begin{array}{l}\text { Fuel container } \\
\text { manifold }\end{array}$} & Fabrication & $\begin{array}{l}\text { The manifold should be fabricated and secured to } \\
\text { minimize vibration }\end{array}$ & $\begin{array}{l}\text { Follow requirements for } \\
\text { manifold }\end{array}$ \\
\hline & Location & $\begin{array}{l}\text { Manifold should be installed in a protected location and } \\
\text { shielded }\end{array}$ & Locations requirements \\
\hline \multirow[t]{3}{*}{$\begin{array}{l}\text { Fuel lines and } \\
\text { connections }\end{array}$} & Installation & $\begin{array}{l}\text { Fuel lines should be mounted, braced, and supported to } \\
\text { minimize vibration and protected against vibration, } \\
\text { strain, and wear }\end{array}$ & $\begin{array}{l}\text { Follow mounting and support } \\
\text { requirements }\end{array}$ \\
\hline & Use of grommets & $\begin{array}{l}\text { Grommets or similar devices should protect fuel lines } \\
\text { that pass through a panel or structural member }\end{array}$ & $\begin{array}{l}\text { Follow penetration } \\
\text { requirements }\end{array}$ \\
\hline & Material use & Aluminum or copper pipe, tubing, or fittings should not & Do not use prohibited material \\
\hline
\end{tabular}




\begin{tabular}{|c|c|c|c|}
\hline & & $\begin{array}{l}\text { be used between the fuel container and the first-stage } \\
\text { pressure regulator }\end{array}$ & \\
\hline & Weight of regulator & $\begin{array}{l}\text { The attached fuel lines should not support the weight of } \\
\text { the regulator }\end{array}$ & $\begin{array}{l}\text { Prohibit support of regulator by } \\
\text { fuel lines }\end{array}$ \\
\hline & Fuel connections & $\begin{array}{l}\text { National Fire Protection Association (NFPA) } \\
\text { NFPA } 52 \text { requires that certain fuel system components } \\
\text { should be listed equipment or materials that meet } \\
\text { identified standards or has been tested and found suitable } \\
\text { for the specified task }\end{array}$ & $\begin{array}{l}\text { Use only listed equipment and } \\
\text { material }\end{array}$ \\
\hline & Hydrostatic test & $\begin{array}{l}\text { Pipe, tubing, fittings, and other piping components } \\
\text { should be capable of withstanding a hydrostatic test of at } \\
\text { least four times the rated service pressure without } \\
\text { structural failure }\end{array}$ & $\begin{array}{l}\text { Follow hydrostatic test } \\
\text { requirement }\end{array}$ \\
\hline & Compatibility & $\begin{array}{l}\text { Pipe, tubing, fittings, gaskets, and packing material } \\
\text { should be compatible with the fuel }\end{array}$ & $\begin{array}{l}\text { Use only materials compatible } \\
\text { with natural gas }\end{array}$ \\
\hline \multirow[t]{5}{*}{$\begin{array}{l}\text { Pressure relief } \\
\text { device (PRD) }\end{array}$} & One PRD per tank & $\begin{array}{l}\text { Each CNG fuel container will have one or more } \\
\text { dedicated PRD }\end{array}$ & Use one PRD per container \\
\hline & Location & $\begin{array}{l}\text { Locate the PRD and tank so they are in the same } \\
\text { compartment (i.e., at the same temperature) }\end{array}$ & $\begin{array}{l}\text { Keep PRD at same temperature } \\
\text { as container being protected }\end{array}$ \\
\hline & Meet standards & $\begin{array}{l}\text { NFPA } 52 \text { requires that certain fuel system components be } \\
\text { listed equipment or materials that meet identified } \\
\text { standards or have been tested and found suitable for the } \\
\text { specified task }\end{array}$ & $\begin{array}{l}\text { Ensure that PRD is listed } \\
\text { component. }\end{array}$ \\
\hline & Location & $\begin{array}{l}\text { The PRD should be in direct communication with the } \\
\text { fuel }\end{array}$ & Ensure proper location \\
\hline & Testing & Each PRD should be tested at least every 5 years & Follow testing requirement \\
\hline \multirow[t]{4}{*}{ Vent line (PRD) } & Orientation & The vent line for the PRD should be vertically oriented & $\begin{array}{l}\text { Ensure proper vent line } \\
\text { orientation }\end{array}$ \\
\hline & Discharge & $\begin{array}{l}\text { The vent line should direct the CNG to the exterior of the } \\
\text { vehicle }\end{array}$ & $\begin{array}{l}\text { Ensure vent line discharge to } \\
\text { exterior }\end{array}$ \\
\hline & Diameter & $\begin{array}{l}\text { The diameter of the vent line should be the same as the } \\
\text { outlet diameter of the PRD }\end{array}$ & $\begin{array}{l}\text { Ensure proper diameter of vent } \\
\text { line }\end{array}$ \\
\hline & Construction & The vent line should be constructed of metal & Use proper material of \\
\hline
\end{tabular}




\begin{tabular}{|c|c|c|c|}
\hline & & & construction. \\
\hline & Vent outlets & $\begin{array}{l}\text { Vent outlets should be protected by caps or covers to } \\
\text { keep water, insects, and dirt from accumulating. The } \\
\text { protective devices should not restrict the flow of gas }\end{array}$ & $\begin{array}{l}\text { Follow vent outlet protection } \\
\text { requirements }\end{array}$ \\
\hline \multirow[t]{4}{*}{$\begin{array}{l}\text { Shutoff valve (for } \\
\text { each container) }\end{array}$} & $\begin{array}{l}\text { Isolation of tank from } \\
\text { remainder of fuel system }\end{array}$ & $\begin{array}{l}\text { Each tank will have a dedicated manual valve or a } \\
\text { normally closed remote actuated shutoff valve that will } \\
\text { allow isolation of each tank from remainder of the fuel } \\
\text { system }\end{array}$ & $\begin{array}{l}\text { Provide dedicated shutoff valve } \\
\text { for each container }\end{array}$ \\
\hline & Location & $\begin{array}{l}\text { Container valves should be protected from physical } \\
\text { damage using the vehicle structure, valve protectors, or a } \\
\text { suitable metal shield }\end{array}$ & $\begin{array}{l}\text { Ensure proper location of } \\
\text { shutoff valve }\end{array}$ \\
\hline & Meet standards & $\begin{array}{l}\text { NFPA } 52 \text { requires that certain fuel system components } \\
\text { (i.e., valves) be listed equipment or materials that meet } \\
\text { identified standards or have been tested and found } \\
\text { suitable for the specified task }\end{array}$ & Use only listed equipment \\
\hline & $\begin{array}{l}\text { Servic e pressure } \\
\text { requirement }\end{array}$ & $\begin{array}{l}\text { Shutoff valves should have a rated service pressure not } \\
\text { less than the rated service pressure of the entire system } \\
\text { and should be capable of withstanding a hydrostatic test } \\
\text { of at least four times the rated service pressure without } \\
\text { rupture }\end{array}$ & $\begin{array}{l}\text { Ensure proper rated service } \\
\text { pressure }\end{array}$ \\
\hline \multirow[t]{2}{*}{$\begin{array}{l}\text { Shutoff valve (for } \\
\text { all containers) }\end{array}$} & $\begin{array}{l}\text { Isolation of all CNG } \\
\text { containers from } \\
\text { remainder of fuel system }\end{array}$ & $\begin{array}{l}\text { There should be a manual valve or a non-closing, remote } \\
\text { actuated shutoff valve that will allow isolation of all } \\
\text { CNG containers from the remainder of the fuel system }\end{array}$ & $\begin{array}{l}\text { Provide shutoff valve for all } \\
\text { CNG containers }\end{array}$ \\
\hline & Pressure and temperature & $\begin{array}{l}\text { Valves, valve packing, and gaskets should be designed or } \\
\text { selected for the fuel over the full range of pressures and } \\
\text { temperatures to which they can be subjected under } \\
\text { normal operating conditions }\end{array}$ & $\begin{array}{l}\text { Use equipment designed for } \\
\text { pressure and temperature } \\
\text { requirements. }\end{array}$ \\
\hline \multirow[t]{2}{*}{$\begin{array}{l}\text { Automatic shut } \\
\text { off valve }\end{array}$} & $\begin{array}{l}\text { Isolation of flow of gas } \\
\text { when engine is not } \\
\text { running }\end{array}$ & $\begin{array}{l}\text { The fuel system should have a valve that automatically } \\
\text { prevents flow of CNG when the engine is not running }\end{array}$ & Provide automatic shutoff valve \\
\hline & Meet standards & $\begin{array}{l}\text { NFPA } 52 \text { requires that certain fuel system components } \\
\text { (i.e., valves) be listed equipment or materials that meet } \\
\text { identified standards or have been tested and found }\end{array}$ & Use only listed equipment \\
\hline
\end{tabular}




\begin{tabular}{|c|c|c|c|}
\hline & & suitable for the specified task & \\
\hline & $\begin{array}{l}\text { Service pressure } \\
\text { requirement }\end{array}$ & $\begin{array}{l}\text { Shutoff valves should have a rated service pressure not } \\
\text { less than the rated service pressure of the entire system } \\
\text { and should be capable of withstanding a hydrostatic test } \\
\text { of at least four times the rated service pressure without } \\
\text { rupture }\end{array}$ & $\begin{array}{l}\text { Ensure valves have proper rated } \\
\text { service pressure requirements }\end{array}$ \\
\hline & Pressure and temperature & $\begin{array}{l}\text { Valves, valve packing, and gaskets should be designed or } \\
\text { selected for the fuel over the full range of pressures and } \\
\text { temperatures to which they can be subjected under } \\
\text { normal operating conditions }\end{array}$ & $\begin{array}{l}\text { Use equipment designed for } \\
\text { pressure and temperature } \\
\text { requirements }\end{array}$ \\
\hline \multirow[t]{2}{*}{$\begin{array}{l}\text { Backflow check } \\
\text { valve }\end{array}$} & $\begin{array}{l}\text { Prevent backflow from } \\
\text { the container to the filling } \\
\text { connection }\end{array}$ & $\begin{array}{l}\text { The fuel system should have a backflow check valve to } \\
\text { prevent backflow from the container to the filling } \\
\text { connection }\end{array}$ & $\begin{array}{l}\text { Provide backflow valve } \\
\text { required }\end{array}$ \\
\hline & Meet standards & $\begin{array}{l}\text { NFPA } 52 \text { requires that certain fuel system components } \\
\text { (i.e., valves) should be listed equipment or materials that } \\
\text { meet identified standards or have been tested and found } \\
\text { suitable for the specified task }\end{array}$ & Use only listed equipment. \\
\hline \multirow[t]{2}{*}{$\begin{array}{l}\text { Pressure } \\
\text { regulator }\end{array}$} & Meet standards & $\begin{array}{l}\text { The fuel system should have automatic pressure reducing } \\
\text { regulators installed to reduce the fuel container pressure } \\
\text { to the level required by the gas-air mixer }\end{array}$ & $\begin{array}{l}\text { Install pressure regulator } \\
\text { required to reduce pressure }\end{array}$ \\
\hline & Meet standards & $\begin{array}{l}\text { NFPA } 52 \text { requires that certain fuel system components } \\
\text { (i.e., pressure regulators) should be listed equipment or } \\
\text { materials that meet identified standards or have been } \\
\text { tested and found suitable for the specified task }\end{array}$ & Use only listed equipment \\
\hline \multirow[t]{2}{*}{ Pressure gauge } & One per CNG fuel system & $\begin{array}{l}\text { The fuel system will have a means to monitor system } \\
\text { pressure }\end{array}$ & $\begin{array}{l}\text { Provide pressure gauge required } \\
\text { to monitor pressure }\end{array}$ \\
\hline & Meet standards & $\begin{array}{l}\text { NFPA } 52 \text { requires that certain fuel system components } \\
\text { (i.e., pressure gauges) be listed equipment or materials } \\
\text { that meet identified standards or has been tested and } \\
\text { found suitable for the specified task }\end{array}$ & Use only listed equipment \\
\hline
\end{tabular}




\section{ACRONYMS}

$\begin{array}{ll}\text { AA } & \text { Aluminum Association } \\ \text { ac } & \text { alternating current } \\ \text { AISI } & \text { American Iron and Steel Institute } \\ \mathrm{CH}_{4} & \text { composition of methane } \\ \text { CNG } & \text { compressed natural gas } \\ \text { dc } & \text { direct current } \\ \text { DOE } & \text { Department of Energy } \\ \text { E-glass } & \text { calcium alumino-borosilicate glass } \\ \text { EMI } & \text { electromagnetic interference } \\ \text { ESA } & \text { electrical signature analysis } \\ \text { GFCI } & \text { ground-fault circuit interrupter } \\ \text { HEV } & \text { hybrid electric vehicle } \\ \text { hp } & \text { horsepower } \\ \text { ICE } & \text { internal-combustion engine } \\ \text { IGBT } & \text { Insulated gate bipolar transistor } \\ \text { KV } & \text { kilovolt } \\ \text { kW } & \text { kilowatt } \\ \text { lb } & \text { pound } \\ \text { M } & \text { meter } \\ \text { mA } & \text { milliampere } \\ \text { msec } & \text { millisecond } \\ - & \text { negative } \\ \text { NFPA } & \text { National Fire Protection Association } \\ \text { NGV } & \text { natural gas vehicle } \\ \text { PRD } & \text { pressure relief device } \\ \text { psi } & \text { pounds per square inch } \\ \text { PWM } & \text { pulse width modulation } \\ \text { RC } & \text { resistor-capacitor } \\ \text { SCC } & \text { stress corrosion cracking } \\ \text { S-glass } & \text { magnesium alumino-silicate glass } \\ \text { TLV } & \text { threshold limit values } \\ \text { V } & \text { volt } \\ \text { Vdc } & \text { volts direct current } \\ \text { Wh/L } & \text { watt-hour per liter } \\ + & \text { positive } \\ & \end{array}$


ORNL/TM-2002/238

\section{INTERNAL DISTRIBUTION}

1-10. S. C. Nelson

11. P. J. Abbott

12. D. J. Adams

13-16. S. D. Curd

17. E. C. Fox

18. R. L. Graves

19. H. E. Knee

20. R. N. McGill

21. J. W. McKeever

22. D. U. O'Kain

23. R. M. Schilling

24. R. E. Ziegler

25. Central Research Library

26. ORNL Laboratory Records-RC

27. ORNL Laboratory Records-OSTI

\section{EXTERNAL DISTRIBUTION}

28. T. Q. Duong, EE-2G/Forrestal Building, U.S. Department of Energy, 1000 Independence Ave., SW, Washington, DC 20585

29. J. J. Eberhardt, EE-2G/Forrestal Building, U.S. Department of Energy, 1000 Independence Ave., SW, Washington, DC 20585

30. S. J. Goguen, EE-2G/Forrestal Building, U.S. Department of Energy, 1000 Independence Ave., SW, Washington, DC 20585

31. G. L. Hagey, EE-33/Forrestal Building, U.S. Department of Energy, 1000 Independence Ave., SW, Washington, DC 20585

32. T. J. Hendricks, U.S. Department of Energy, National Renewable Energy Laboratory, MS1633, 1617 Cole Blvd, Golden, CO 80401

33. K. C. Howden, EE-2G/Forrestal Building, U.S. Department of Energy, 1000 Independence Ave., SW, Washington, DC 20585

34. R. S. Kirk, EE-2G/Forrestal Building, U.S. Department of Energy, 1000 Independence Ave., SW, Washington, DC 20585

35. R. A. Kost, EE-2G/Forrestal Building, U.S. Department of Energy, 1000 Independence Ave., SW, Washington, DC 20585

36. R. P. Larsen, U.S. Department of Energy, Argonne National Laboratory, 9700 S Cass Avenue, Building 362, Argonne, IL 60439

37. S. A. Rogers, EE-2G/Forrestal Building, U.S. Department of Energy, 1000 Independence Ave., SW, Washington, DC 20585

38. L. A. Slezak, EE-2G/Forrestal Building, U.S. Department of Energy, 1000 Independence Ave., SW, Washington, DC 20585

39. K. C. Stork, EE-2G/Forrestal Building, U.S. Department of Energy, 1000 Independence Ave., SW, Washington, DC 20585 